OECD Economics Department Working Papers No. 665

Health Care Reform in the United States

\title{
David Carey,
}

Bradley Herring,

Patrick Lenain 
Organisation de Coopération et de Développement Économiques

Organisation for Economic Co-operation and Development

06-Feb-2009

ECONOMICS DEPARTMENT

English - Or. English

HEALTH CARE REFORM IN THE UNITED STATES

ECONOMICS DEPARTMENT WORKING PAPER No. 665

By David Carey, Bradley Herring and Patrick Lenain

All Economics Department Working Papers are available through OECD's internet web site at www.oecd.org/eco/Working Papers.

JT03259332

Document complet disponible sur OLIS dans son format d'origine

Complete document available on OLIS in its original format 


\section{ABSTRACT/RÉSUMÉ \\ Health Care Reform in the United States}

In spite of improvements, on various measures of health outcomes the United States appears to rank relatively poorly among OECD countries. Health expenditures, in contrast, are significantly higher than in any other OECD country. While there are factors beyond the health-care system itself that contribute to this gap in performance, there is also likely to be scope to improve the health of Americans while reducing, or at least not increasing spending. This paper focuses on two factors that contribute to this discrepancy between health outcomes and health expenditures in the United States: inequitable access to medical services and subsidized private insurance policies; and inefficiencies in public health insurance. It then suggests two sets of reforms likely to improve the US health-care system. The first is a package of reforms to achieve close to universal health insurance coverage. The second set of reforms relates to payment methods and coverage decisions within the Medicare programme to realign incentives and increase the extent of economic evaluation of different medical procedures.

JEL classification: $\mathrm{H} 51 ; \mathrm{I} 12 ; \mathrm{O} 57$; $\mathrm{C} 23$.

Key words: Health outcomes; life expectancy; health status; health costs; health expenditure; health insurance; pooling; individual market; adverse selection; moral hazard; mandate; health subsidies; tax exclusion; Medicare; Medicare Advantage; comparative effectiveness.

\section{Réforme du système de santé aux États Unis}

Malgré certains progrès, les États-Unis ne sont pas très bien placés parmi les pays de l'OCDE pour ce qui est de diverses mesures des résultats de la santé. Or, les dépenses de santé y sont sensiblement plus élevées que dans tout autre pays de l'OCDE. Cette situation contradictoire amène à penser qu'il est possible d'améliorer le système de santé du pays tout en réduisant, ou du moins en n'augmentant pas, les dépenses. Le présent papier examine plus particulièrement deux facteurs qui contribuent à la divergence entre les résultats et les dépenses en matière de santé aux États-Unis : accès inéquitable aux services médicaux et inefficience des subventions pour la souscription de polices d'assurance privées; et manque d'efficacité de l'assurance de santé publique. Il propose ensuite deux séries de réformes propres à améliorer le système de santé des États-Unis. La première est un ensemble de mesures destinées à assurer la couverture universelle de l'assurance-maladie. La deuxième concerne les méthodes de paiement et les décisions de prise en charge au sein du programme Medicare et vise à réaligner les incitations et à renforcer l'évaluation économique des différents actes médicaux.

Classification JEL : H51 ; I12 ; O57 ; C23

Mots clés: Résultats de la santé; espérance de vie; coûts de santé; les dépenses de santé; assurance santé; regroupement de risque; marché individuel; sélection adverse; aléa moral; mandat; subventions pour l'achat des polices d'assurance santé ; l'exonération fiscale; Medicare Avantage ; comparaison de l'efficacité.

\section{Copyright OECD 2007}

Application for permission to reproduce or translate all, or part of, this material should be made to : Head of Publication Service, OECD, 2 rue André-Pascal, 75775 Paris Cedex 16, France. 


\section{TABLE OF CONTENTS}

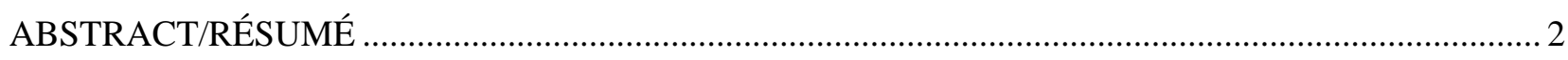

HEALTH CARE REFORM IN THE UNITED STATES ................................................................. 5

Population health status is lower and health expenditure is higher than in many other OECD countries .. 7 Population health status is falling behind that in other developed countries ...................................... 7

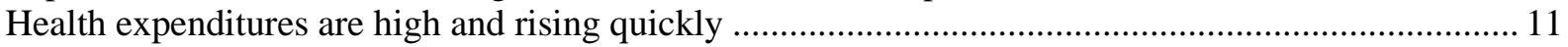

Efficiency of the health-care system - health status in relation to inputs ........................................... 19

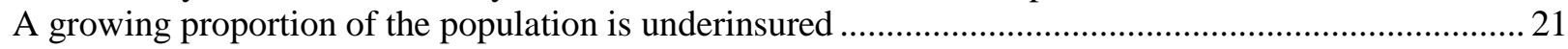

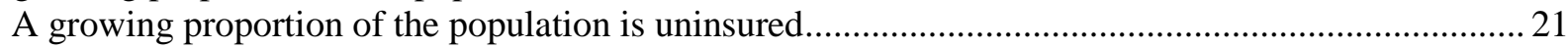

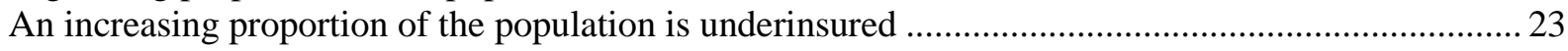

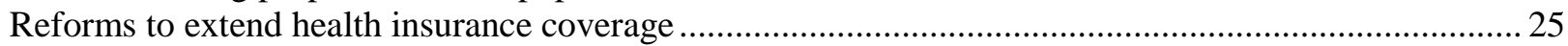

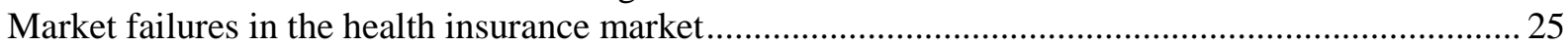

Reforms to expand insurance coverage and to improve health outcomes in relation to health costs .... 27

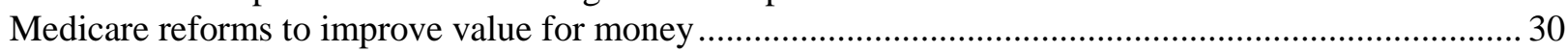

Create a Comparative Effectiveness Institute ................................................................................. 31

Decrease the generosity of supplemental Medicare insurance designs for beneficiaries without chronic

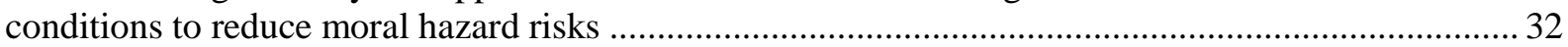

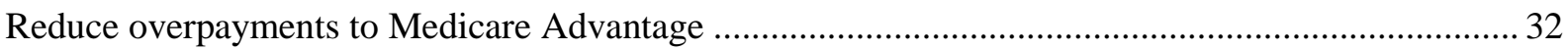

Use competitive tenders for purchases of medical equipment and supplies ......................................... 33

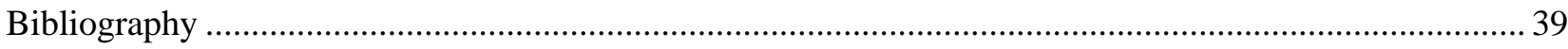

\section{Tables}

1. Health care workforce per 1000 population and physician incomes, 2006....................................... 16

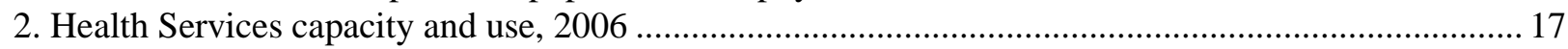

3. Availability and use of sophisticated medical technologies, 2006 .................................................. 18

4. Adults ages 19-64 who were uninsured or underinsured, by various characteristics ......................... 22

5. New insurance pool for individuals and small groups with subsidies and changed tax exclusions...... 29

\section{Figures}

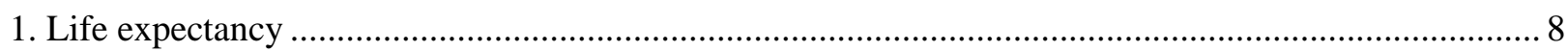

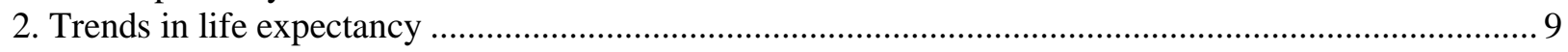

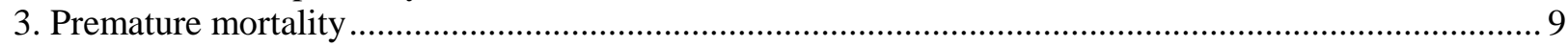

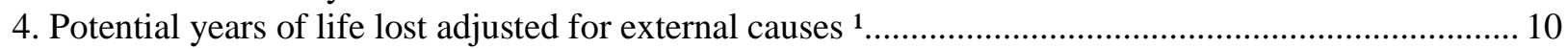

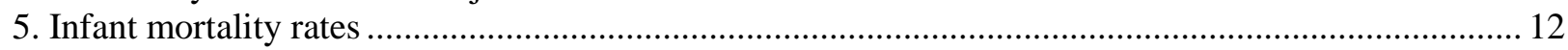

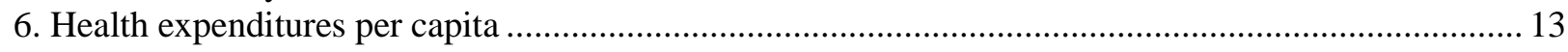

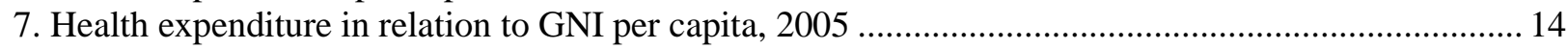


8. Panel regressions: years of life which are not explained by the general model 20

9. Average annual health-care expenditures, by wage status ........................................................... 24

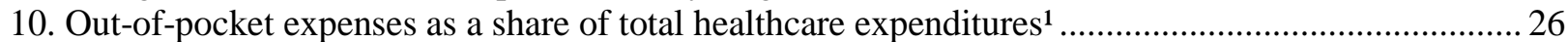

\section{Boxes}

Box 1. Some health-care reform proposals in the public domain ..................................................... 5

Box 2 The gap in health-care services between high- and low-wage workers is widening .....................24

Box 3. The origins and budget cost of employment-based health insurance …...................................... 26

Box 4. The health-insurance reform package in Gruber's (2008) micro-simulation .................................. 28

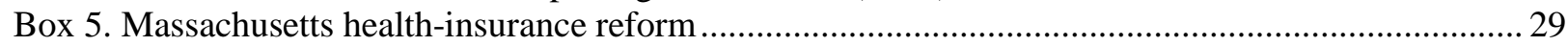

Box 6. The Sustainable Growth Rate mechanism to control growth in Medicare expenditure on

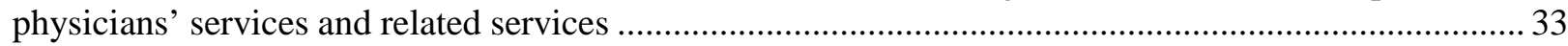

Box 7. Recommendations for improving value for money and insurance coverage in health care .......... 33 


\title{
HEALTH CARE REFORM IN THE UNITED STATES
}

\author{
By David Carey, Bradley Herring and Patrick Lenain ${ }^{1}$
}

1. The US health-care system has many attractive features: in particular, most of the population has access to high standards of medical care, which are being continuously enhanced through cutting edge technological innovation. Nevertheless, the overall health status of the US population, as reflected in variables such as life expectancy and potential years of life lost, appears to rank among the lower third of OECD countries, despite much higher health expenditure per capita than in any other country. While many factors other than the performance of the health-care system affect health, the US health-care system can make a greater contribution to improving the health status of the US population without increasing expenditure, including by expanding access to health care. According to the 2008 Economic Report of the President, there are "substantial opportunities for reforms that would reduce costs, increase access, enhance quality, and improve the health of Americans". Seizing these opportunities would thus contribute to achievement of the main objectives of the US Department of Health and Human Services (since 1990), namely: to reduce and ultimately eliminate health inequalities among various segments of the US population, including those among gender, ethnic, socioeconomic and geographic groups; and to increase life expectancy and quality of life among Americans of all ages.

2. There is growing public concern about rapidly increasing health costs and the growing number of uninsured people. In the longer term, rising Medicare expenditure is the main threat to the sustainability of public finances. Federal policymakers have tried to address these challenges with incremental reforms, including a shift to managed-care organisations (HMOs and PPOs), the introduction of health-savings accounts and reforms to Medicare. However, these reforms have not succeeded in containing the growth of health-care spending and there has been a trend increase in the number of uninsured and underinsured. Recently there has been a spate of proposals for health-care reform, including from both the major 2008 Presidential candidates (Box 1), and some significant reforms have occurred at the state level.

\section{Box 1. Some health-care reform proposals in the public domain}

\section{Health-care reform plans of the main 2008 presidential candidates}

\section{Mr McCain (Republican)}

The McCain proposals for health-care reform aim to reduce costs by strengthening market competition. By making health care more affordable, these reforms are intended to make health insurance more accessible. The main reforms envisaged entail:

- $\quad$ Creating a uniform refundable tax credit (\$2 500 for singles, and $\$ 5000$ for families) to replace the (open-

\footnotetext{
${ }^{1}$ The authors would like to thank Elizabeth Docteur and her colleagues in the Health Division of the Directorate for Employment, Labour and Social Affairs, Robert Ford, Andrew Dean, Isabelle Joumard and Christophe André for valuable comments on earlier drafts. Special thanks go to Jessica Hoel, Laure Meuro, Roselyne Jamin for statistical assistance and to Heloise Wickramanayake for technical preparation. David Carey and Patrick Lenain work in the OECD Economics Department while Bradley Herring is a professor at John Hopkins University. The views expressed in this paper are those of the authors and do not necessarily reflect the position of the OECD in its member countries.
} 
ended) employment-based tax exclusion.

- $\quad$ Allowing individuals and small groups to buy health insurance nationwide instead of just from companies in their own state, which would circumvent state legal requirements (mandates) on the content of insurance policies and the conditions under which they can be sold, such as the degree of experience-rating that is permitted.

- Establishing a Guaranteed Access Plan in co-operation with states for individuals with pre-existing conditions who have been denied insurance.

- Developing routes for cheaper generic versions of drugs to enter the US market, including allowing for reimportation of drugs.

- Revamping Medicare payment systems to pay providers for diagnosis, prevention and care coordination without paying them for preventable medical errors or mismanagement.

- $\quad$ Reforming medical liability laws to eliminate lawsuits for doctors that follow clinical guidelines and adhere to patient safety protocols, and to cap damages awards.

- Increasing the focus on prevention, including through the use of drugs to manage conditions such as diabetes; and

- Improving the quality of purchasing decisions by using data from digital medical records and from comparative effectiveness trials.

The McCain team does not provide cost estimates for these proposals.

\section{Mr Obama (Democrat)}

The Obama health-care reform programme aims to achieve universal health insurance coverage, to reduce health-care costs, and to improve the functioning of the public health-care system. The centrepiece the programme is a package of measures to make insurance more affordable, by:

- $\quad$ Creating a National Health Insurance Exchange with a range of private insurance options where individuals without company plans can buy a private or a new public plan based on the benefits available to members of Congress.

- $\quad$ Establishing a minimum federal standard for the plans offered on the Exchange.

- Requiring that all individual insurance plans be community rated (to prevent companies off the Exchange from selecting healthy patients, leaving only the unhealthy in the Exchange).

- Giving tax credits ( $\$ 110$ billion - $\$ 120$ billion) for low- and middle-income people to buy insurance; and

- Considering the introduction of a legal requirement (mandate) to have insurance coverage once this system is up and running.

Such a reform programme should reduce administrative costs (mainly underwriting costs to reduce adverse selection risks). Other measures to improve the effectiveness of the health-care system in relation to costs include:

- Increasing the focus on prevention, including through the use of drugs to manage conditions such as diabetes; and

- Improving the quality of purchasing decisions by using data from digital medical records - $\$ 10$ billion per year over five years has been set aside to put medical records online - and from comparative effectiveness trials.

The net cost of the whole plan after planned savings is estimated by the Obama team to be $\$ 50$ billion- $\$ 65$ billion per year. This would be paid for by allowing the tax cuts introduced by President Bush's administration for high-income households to lapse.

\section{Health insurance reform proposals presented to the $110^{\text {th }}$ Congress}

Many different pieces of health insurance legislation have been introduced to the $110^{\text {th }}$ Congress ( 3 January 
2007 - 3 January, 2009). According to the Congressional Research Service (CRS, 2008), these reform bills have had a variety of primary objectives, including to:

- $\quad$ Reduce the number of people without health insurance.

- $\quad$ Reduce the reliance on health insurance for at least some part of needed medical care; and

- Reduce the cost of health insurance.

The CRS (2008) classifies these reform bills into the following categories:

- National Health Insurance (i.e., a social insurance approach) or a National Health Service (universal coverage and reform of some or all factors of health-care production).

- Expansion of existing public programmes (Medicare, Medicaid, and the State Children's Health Insurance Program (SCHIP)).

- Expansion of privately sponsored coverage, including proposals to:

- Expand employer-based health insurance.

- Expand the individual market for health insurance; and

- Improve the private market for health insurance.

- Implementation of state-based reforms; and

- Combinations of the above approaches.

More information about these proposals can be found in the CRS document http://www.cahc.net/RL34389.pdf

3. This paper begins with an examination of data on health status and health expenditure in the United States, in comparison with other OECD countries. The second section discusses access to health-care services in the United States. The third section looks at reforms to expand financial access to health care through private insurance while the final section considers Medicare reforms to improve value for money. Policy recommendations are summarised in the box at the end of the chapter.

\section{Population health status is lower and health expenditure is higher than in many other OECD countries}

\section{Population health status is falling behind that in other developed countries}

4. Population health status reflects performance of the health-care system amongst other factors. On the criteria of life expectancy, infant mortality and amenable mortality, for which we have reasonably reliable cross-country data, health status in the United States does not compare favourably with that in most other OECD countries. Other contributions of the health-care system to health status, such as quality of life associated with the reduction of symptoms and improved functional status are also important, as is the absence of waiting lists for elective surgery. Unfortunately, reliable data are not available to make cross-country comparisons on these aspects of health status, which could very well show the United States in a more favourable light.

5. Life expectancy at birth has continued to rise markedly over recent decades, increasing in the United States from an average of 70.2 years in 1960-62 to an average of 77.7 years in 2003-05. This increase was smaller than in most other OECD countries, especially so for women, and as a result US life expectancy at birth fell from above the OECD average to below it (Figures 1, 2 and 3). While some of the difference in life expectancy between countries can be attributed to the probability of death from violence 
or accidents, ${ }^{1}$ this factor does not appear to explain the lower increase in life expectancy in the United States. Potential years of life lost (PYLL) for persons aged less than 70, adjusted for non-health related causes of death ${ }^{2}$, have also declined by less in the United States (Figure 4). It should also be noted that these comparisons do not adjust for country-specific changes in demographic composition and differences in life style, which may also help to explain the pattern.

Figure 1. Life expectancy

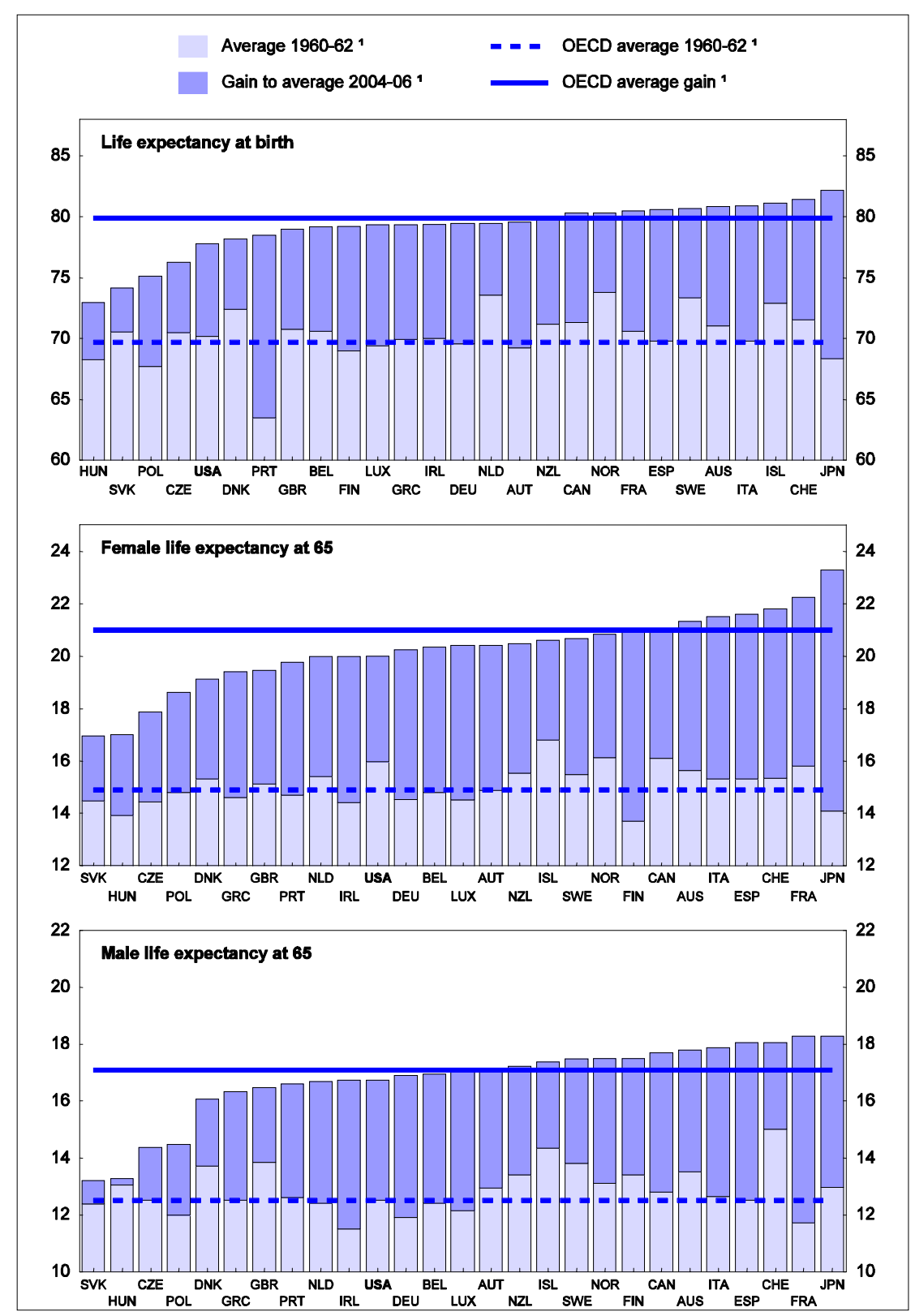

1. Population weighted average of countries shown, excluding the United States. For Iceland, gains between 1963 and $2004-2006$ average.

Source: OECD Health Data (2008). 
Figure 2. Trends in life expectancy ${ }^{1}$

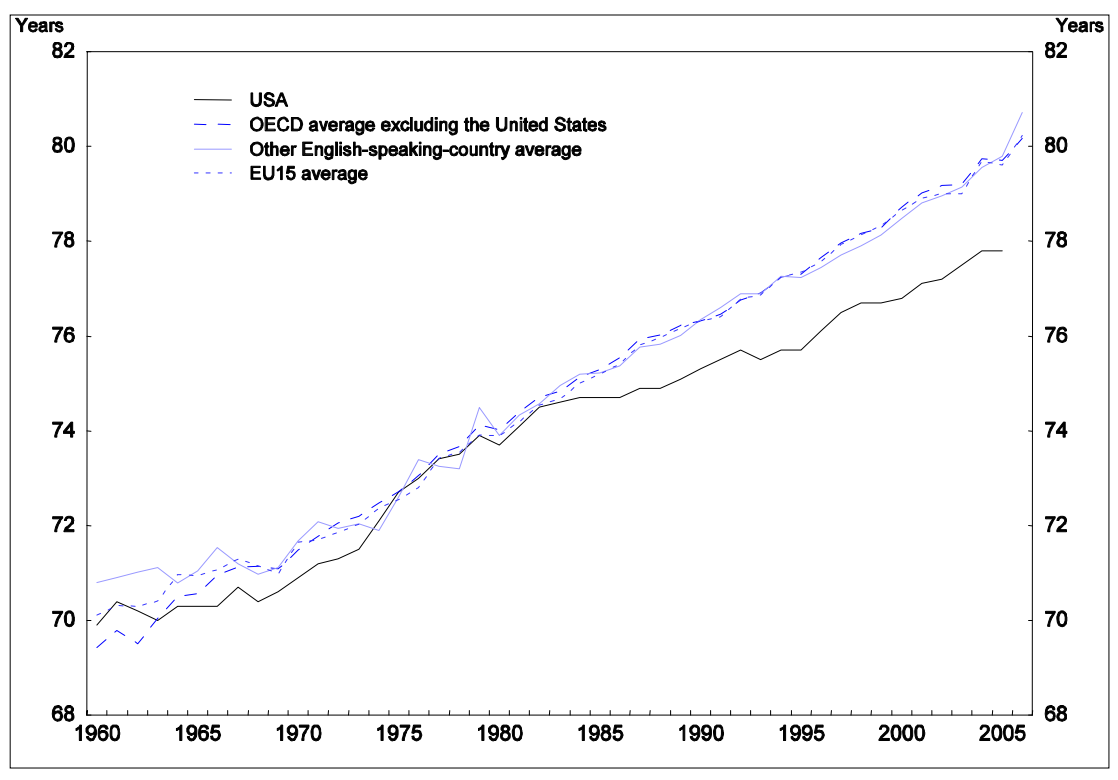

1. Averages are population weighted. Also excludes Korea, Mexico, and Turkey.

Source: OECD Health Data (2008).

Figure 3. Premature mortality

Percentage of potential years lost attributable to external causes ${ }^{1}$

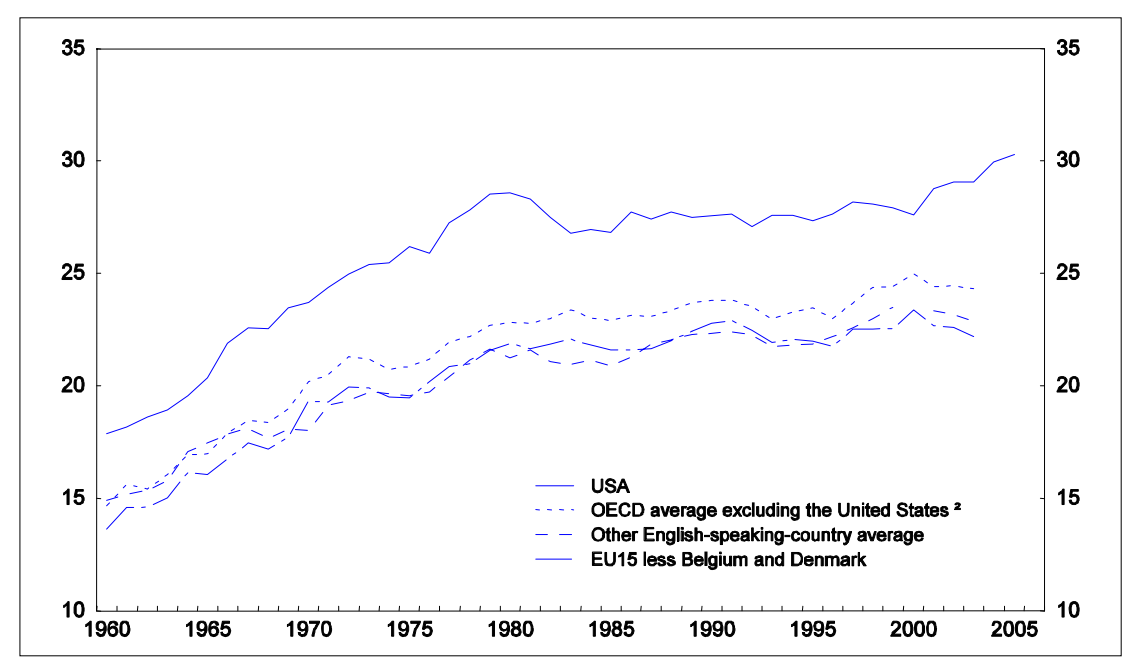

1. Analysis for the population aged 0-69 years. Averages are population weighted. External causes include: land transport accidents; intentional self harm; accidental falls; and assaults.

2. OECD average excludes Belgium, the Czech Republic, Denmark, Korea, Mexico, the Slovak Republic, and Turkey in addition to the United States.

Source: OECD Health Data (2008). 
Figure 4. Potential years of life lost adjusted for external causes ${ }^{1}$

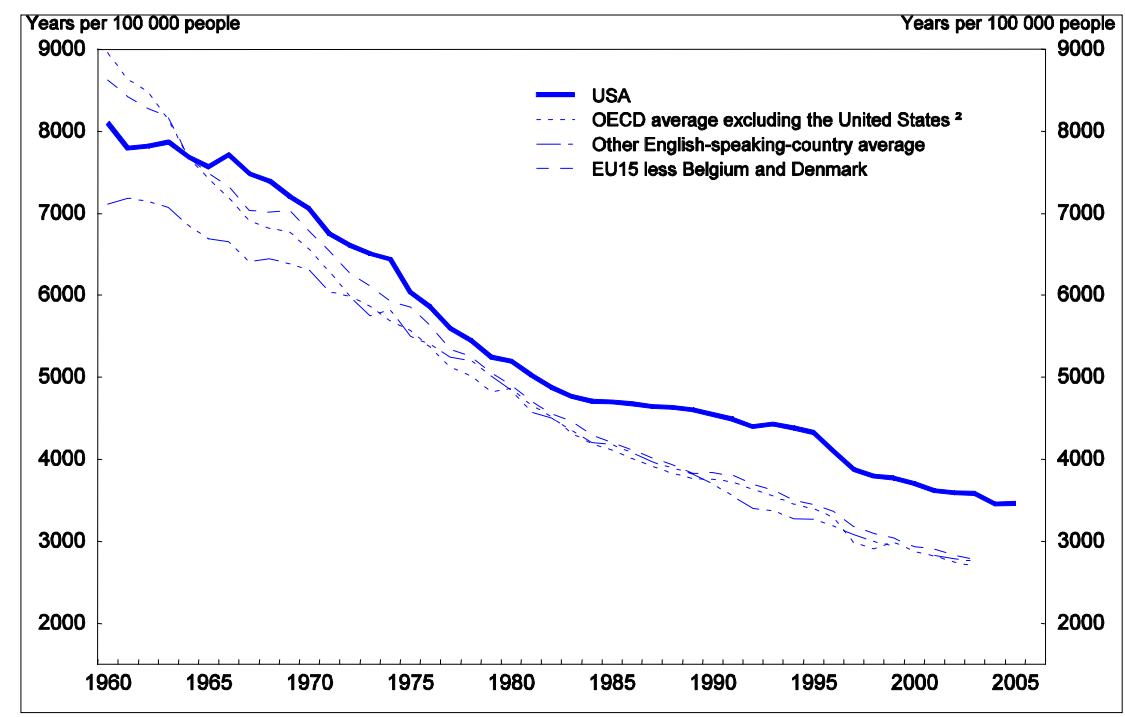

1. Analysis for the population aged 0-69 years. Averages are population weighted. External causes include: land transport accidents; intentional self harm; accidental falls; and assaults.

2. OECD average excludes Belgium, the Czech Republic, Denmark, Korea, Mexico, the Slovak Republic, and Turkey in addition to the United States.

Source: OECD Health Data (2008).

6. The increase in life expectancy in the United States at age 65 has also been less than the OECD average for both women and men, and since the early 1960s the US rank among OECD countries has fallen slightly for men but markedly for women. As in most other OECD countries, percentage gains in life expectancy at age 65 (33\% for men and 25\% for women in the United States versus OECD averages of $37 \%$ for men and $41 \%$ for women) have been considerably larger than at birth (12\% for males and $10 \%$ for females in the United States versus OECD averages of $15 \%$ for both males and females).

7. Gaps in life expectancy between socio-economic groups have increased markedly in the United States in recent decades. Life expectancy at birth increased by 3.4 years between 1980-82 and 1998-2000 (to 79.2 years) for the least socioeconomically deprived tenth of the population, but by only 1.4 years (to 74.7 years) for the most socioeconomically deprived tenth of the population (Singh and Siahpush, 2006). ${ }^{3}$ At age 65, the gap in life expectancy for these two groups rose from 0.3 years in 1980-82 to 1.6 years in 1998-2000. The increase in this gap accounts for more than half of the rise in the gap in life expectancy at birth. ${ }^{4}$ This pattern of widening inequalities in life expectancy contrasts with that observed in the United States between 1930 and 1960 (Kitagawa and Hauser, 1973), and with the experience in urban Canada between 1971 and 1996 (Wilkins, Bathelot and Ng, 2002). On the other hand, socioeconomic inequality in life expectancy has also increased in Great Britain, other European countries and New Zealand in recent decades (Hattersly, 1999; Kunst et al, 2004 and New Zealand Department of Health, Social Report, 2007). It is difficult to assess whether the gap in life expectancy between socioeconomic groups and its increase is large by international comparison because of differences in methodologies used in the various studies. The increasing inequality in life expectancy between socioeconomic groups runs counter to one of the main objectives of the US Department of Health and Human Services since 1990, namely to reduce and ultimately eliminate health inequalities among various segments of the US population, including those among gender, ethnic, socioeconomic and geographic groups; the other broad health goal for the nation seeks to increase life expectancy and quality of life among Americans of all ages (Singh and Siahpush, 2006, p. 969). 
8. Another health status indicator that reflects the performance of the health-care system along with other economic and social factors ${ }^{5}$ is the infant mortality rate (i.e., the rate at which babies of less than one year die). Like life expectancy, the infant mortality rate has also improved substantially in recent decades, falling from an average of 25.5 per thousand live births in 1960-62 to 6.9 per thousand live births in 2004-06 (Figure 5). Again, this reduction is less than the OECD average, taking US infant mortality rates from below the OECD average to above it; US infant mortality rates are currently amongst the highest in the OECD.

9. A factor to bear in mind when interpreting these mortality rates is that part of the international variation may be attributable to differences amongst countries in registering practices of premature infants (whether they are reported as live births or foetal deaths) (OECD, 2007). In the United States, as well as in Canada, Japan, and the Nordic countries, very premature babies with relatively low odds of survival are registered as live births, a practice that increases mortality rates compared with countries that do not register them as live births. Nevertheless, infant mortality has also declined more in all of the countries with the same registration practices as the United States, and has fallen to much lower levels than in the United States. Even if there were uniform reporting standards of infant mortality across countries, a second limitation to using it as an indicator for health outcomes is the potential effect of certain interventions on the likelihood of a live birth. It is conceivable that additional health care provided in the second or third trimester causes a pregnancy that would almost assuredly be a stillborn to become a pregnancy with an improved chance of a live birth but also an above-average likelihood of dying within the first year. These interventions increase health care expenditures and result in the birth of more low-weight- and very low-weight babies, with significantly greater health problems. It is not clear whether or not this factor helps to explain the apparent smaller decline and higher rates of infant mortality in the United States than in other countries. In addition to the above caveats, there may be other factors, including the mother's behaviour (e.g., smoking) and demographic factors (e.g., teen births), that are changing over time and contribute to the observed pattern of infant mortality that are independent of health-care system efficacy.

10. The United States also appears to be lagging other countries in reducing "amenable mortality"deaths from certain causes that should not occur in the presence of timely and effective health care. Nolte and McKee (2008) examine recent trends in deaths from treatable conditions and find that while the United States was comparable to other OECD countries in 1997-1998, it ranked near the bottom in 2002-2003. The authors note, however, several potential data and measurement issues when comparing aggregate data across countries, including differences in interpretation regarding the concept of amenable mortality and reporting issues relating to conversion to the ICD- $10^{6}$ system. The authors also find large regional differences in amenable mortality. They estimate that if all states achieved levels seen in the bestperforming state, about 90000 premature deaths could be avoided annually, compared with 101000 if the United States were to achieve levels of amenable mortality seen in the three top-performing countries. They also note that US underperformance on this measure has coincided with an increase in the uninsured population (see below).

\section{Health expenditures are high and rising quickly}

11. Health expenditures per capita in the United States are by far the highest among OECD countries (Figure 6). The public share of health expenditure (46\%) is much lower than in any other OECD country, except Mexico, but nevertheless public health expenditure per capita is higher than in most other OECD countries. ${ }^{7}$ For this amount of expenditure in the United States, government provides insurance coverage only for the elderly and disabled (through Medicare, which primarily insures persons aged 65 or over and individuals with disabilities and end-stage renal disease) and some of the poor (through Medicaid and the State Children's Health Insurance Program (SCHIP)), whereas in most other OECD countries this is enough for government to provide universal primary health insurance. 
Figure 5. Infant mortality rates

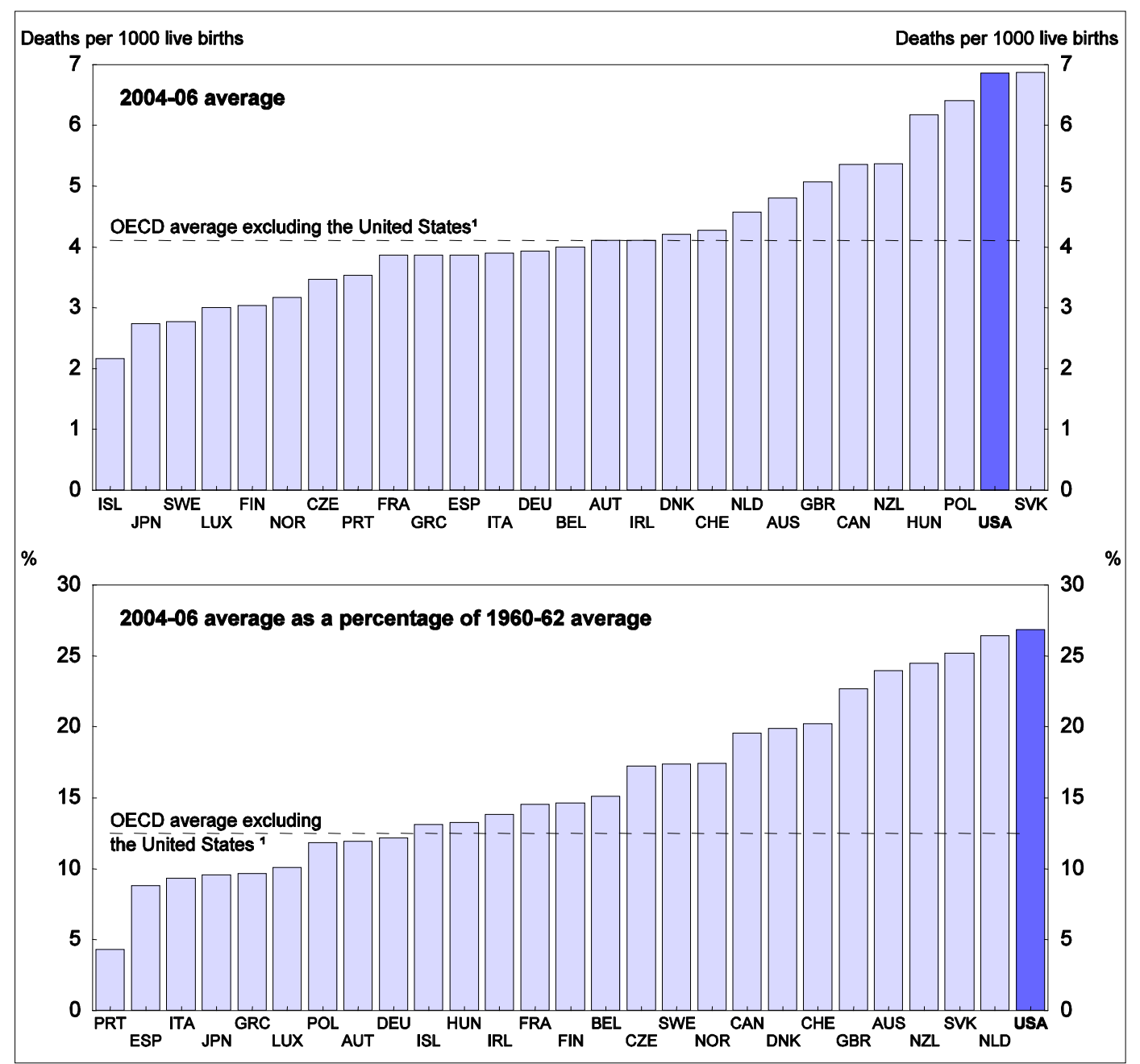

1. OECD average is population weighted and excludes Korea, Mexico, and Turkey in addition to the United States.

Source: OECD Health Data (2008).

12. Real growth in health expenditure per capita over the past quarter century has also been considerably higher in the United States than in most other OECD countries (see Figure 6). Growth in public health expenditures was somewhat higher in the United States than in private health expenditures, because of one-time savings in private health insurance from the shift to managed care in the form of Health Maintenance Organisations (HMOs) and Preferred Provider Organisations (PPOs). Health expenditure per capita across OECD countries is positively related to GNI per capita (Figure 7). However, higher income levels in the United States only explain part of its high health spending. 
Figure 6. Health expenditures per capita

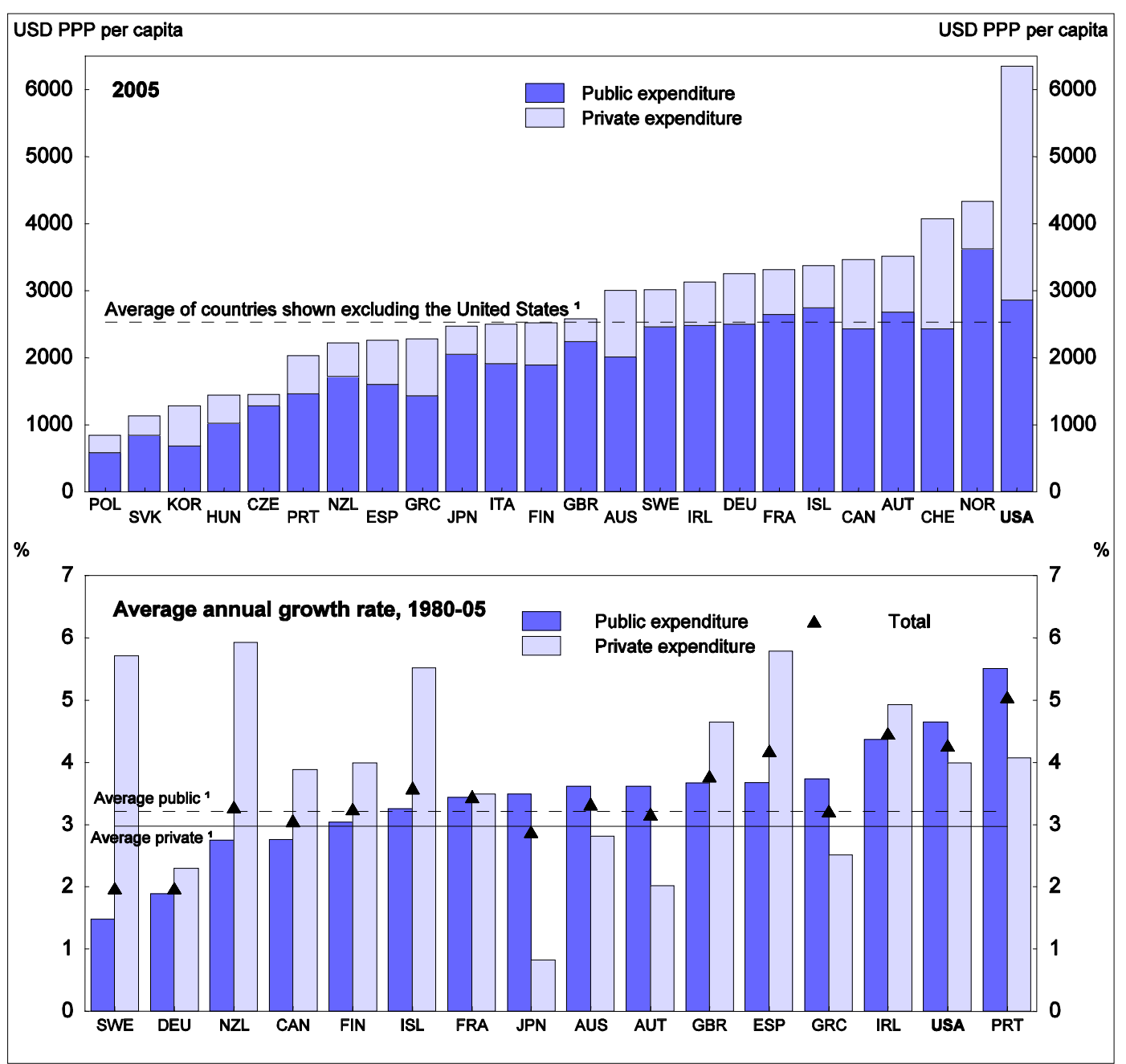

1. Averages are population weighted.

Source: OECD Health Data (2008). 
Figure 7. Health expenditure in relation to GNI per capita, $2005^{1}$

Thousand of USD PPP

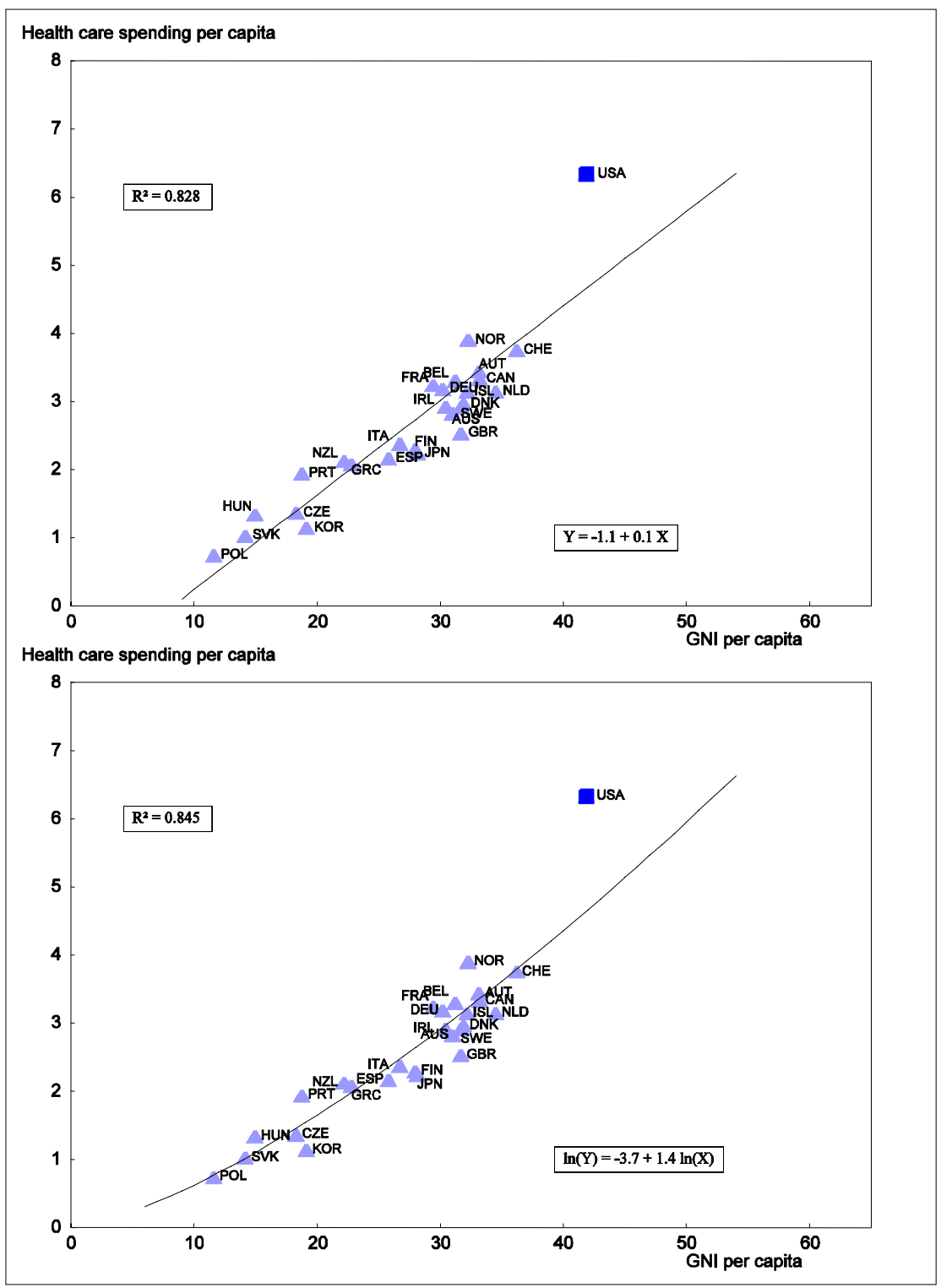

1. These figures display GNI per capita with respect to real total health spending per capita. They exclude Luxembourg, Mexico, and Turkey. The data point for Norway displays mainland GNI per capita. The non-linear regression line in the second panel suggests that health spending may increase more than proportionally with rising income.

Source: OECD, Health data (2008).

High health expenditure in the United States may partly reflect high relative prices for health-care services

13. It is difficult to judge whether the high level of health expenditures in the United States mainly reflects high volumes of health-care services or high relative prices for health care - satisfactory purchasing power parity exchange rates for health-care services are unavailable. Nevertheless, the crude indicators of health-care service volumes that are available point to volumes in the United States not being out of line with those in other OECD countries, suggesting that high prices may be a factor contributing to high expenditures (Tables $1,2,3) .{ }^{8}$ Physician density is below the OECD median, as are physician visits 
per capita, while nurse density is slightly higher and hospital use is clearly lower. On the other hand, the availability and use of sophisticated medical technologies is significantly higher than in most other countries, except Japan (which has lower per capita health-care spending than the United States). Physician incomes relative to GDP per capita are high by international comparison, lending support to the view that high prices contribute to high expenditures in the United States. The relatively high physician incomes in the United States are likely mainly to reflect the relatively high compensation for professionals in general compared with that in other countries.

14. Likewise, pharmaceutical drug prices appear to be higher in the United States than in other OECD countries. Danzon and Furakawa (2008) find that price indexes of drugs in 12 countries indicate that foreign prices are up to $20 \%$ lower than public prices in the United States, even though prices of generic drugs are higher. This pricing pattern probably reflects the price controls imposed in many countries, but not in the United States, where the authorities do not interfere in the determination of drug prices in either non-public programmes or Medicare (Part D). ${ }^{9}$ It might also, however, reflect less price elastic demand in the United States and, therefore, price discrimination by monopolistic (owing to patent protection) drug manufacturers. Either way, the relatively high prices paid for patented drugs in the United States strengthen incentives for the development of more effective drugs, which also benefit patients in other (notably OECD) countries.

15. High health expenditures in the United States may also reflect to some extent high costs beyond those strictly related to the delivery of health-care services. Angrisano et al. (2007) estimate that US health expenditure in 2005 was $\$ 477$ billion (out of a total of $\$ 1.9$ trillion) higher than in peer countries (Japan, Germany, France, Italy, Spain, and the United Kingdom) after adjusting for GDP per capita and that $36 \%$ of this amount was attributable to higher intermediation $\operatorname{costs}^{10}$ (\$98 billion) and to higher profits and taxes on them ( $\$ 75$ billion). 
Table 1. Health-care workforce per 1000 population and physician incomes, 2006

ECO/WKP(2009)6

\begin{tabular}{l|l} 
Per 1000 population & Income ratio to GDP per capita
\end{tabular}

\begin{tabular}{|c|c|c|c|c|c|c|c|c|}
\hline \multicolumn{5}{|c|}{ Per 1000 population } & \multicolumn{4}{|c|}{ Income ratio to GDP per capita } \\
\hline & \multirow[t]{2}{*}{ Physicians } & \multirow{2}{*}{$\begin{array}{l}\text { Practicing } \\
\text { specialists }\end{array}$} & \multirow[t]{2}{*}{ Practicing GPs } & \multirow[t]{2}{*}{ Nurses } & \multicolumn{2}{|c|}{ Specialists } & \multicolumn{2}{|c|}{ General practitioners } \\
\hline & & & & & Salaried & Self employed & Salaried & Self employed \\
\hline Australia & $2.8^{1}$ & $1.3^{1}$ & $1.4^{1}$ & $9.7^{1}$ & $\ldots$ & $5.2^{1}$ & $\ldots$ & $2.5^{1}$ \\
\hline Austria & 3.6 & 2.1 & 1.5 & 7.3 & $\ldots$ & 7.4 & $\ldots$ & $3.4^{3}$ \\
\hline Belgium & 4.0 & 2.0 & 2.1 & 14.8 & $\ldots$ & 7.6 & $\ldots$ & 2.4 \\
\hline Canada & 2.1 & 1.1 & 1.0 & 8.8 & $\ldots$ & $4.9^{1}$ & $\ldots$ & $3.2^{1}$ \\
\hline Czech Republic & 3.6 & 2.8 & 0.7 & 8.1 & & $2.3^{1}$ & $\cdots$ & $1.8^{1}$ \\
\hline Denmark & $3.6^{2}$ & $2.3^{2}$ & $0.8^{2}$ & 15.3 & $2.8^{1}$ & $\ldots$ & 1.8 & $\ldots$ \\
\hline Finland & 2.7 & 1.6 & 0.7 & 8.3 & 2.6 & 4.8 & $\ldots$ & 2.8 \\
\hline France & 3.4 & 1.7 & 1.7 & 7.6 & $\ldots$ & 4.5 & $\ldots$ & 3.6 \\
\hline Germany & 3.5 & 2.5 & 1.0 & 9.8 & & & $\ldots$ & $\ldots$ \\
\hline Greece & $5^{1}$ & $3.3^{1}$ & $0.3^{1}$ & $3.3^{1}$ & $2.6^{1}$ & $2.7^{2}$ & & $\begin{array}{l}\cdots \\
\cdots\end{array}$ \\
\hline Hungary & 3.0 & 2.1 & 0.7 & 6.1 & 1.7 & $\ldots$ & 1.6 & $\ldots$ \\
\hline Iceland & 3.7 & 2.2 & 0.7 & 13.7 & $2.9^{1}$ & $\ldots$ & $3.0^{1}$ & \\
\hline Ireland & 2.9 & 0.8 & 0.5 & 15.4 & 4.0 & $\ldots$ & $\ldots$ & 4.3 \\
\hline Italy & 3.7 & $\ldots$ & 0.9 & 7.1 & $\ldots$ & $\ldots$ & $\ldots$ & $\ldots$ \\
\hline Japan & 2.1 & $\ldots$ & $\ldots$ & 9.3 & $\ldots$ & $\ldots$ & $\ldots$ & $\ldots$ \\
\hline Korea & 1.7 & 1.1 & 0.6 & 4.0 & & $\ldots$ & $\ldots$ & $\ldots$ \\
\hline Luxembourg & 2.8 & 2.0 & 0.8 & 16.0 & $2.3^{1}$ & $3.5^{1}$ & $1.6^{1}$ & $1.8^{1}$ \\
\hline Mexico & 1.9 & 1.3 & 0.6 & 2.3 & 3.6 & 8.4 & 3.3 & $\ldots$ \\
\hline Netherlands & $\ldots$ & 0.7 & 0.5 & 8.6 & 3.8 & 8.3 & $\ldots$ & 3.4 \\
\hline New Zealand & 2.3 & 0.8 & 0.8 & 10.0 & 3.6 & $\ldots$ & $\ldots$ & $\ldots$ \\
\hline Norway & 3.7 & 2.1 & 0.8 & 31.6 & 1.5 & $\ldots$ & $\ldots$ & \\
\hline Poland & 2.2 & 1.8 & 0.1 & 5.1 & & & $\cdots$ & $\ldots$ \\
\hline Portugal & & $1.7^{1}$ & $1.7^{1}$ & $4.6^{1}$ & $3.3^{1}$ & $\ldots$ & $\ldots$ & $\begin{array}{l}\cdots \\
\cdots\end{array}$ \\
\hline Slovak Republic & $3.1^{2}$ & $2.3^{2}$ & $0.4^{3}$ & $6.3^{2}$ & $\ldots$ & $\ldots$ & $\ldots$ & $\ldots$ \\
\hline Spain & 3.6 & 1.9 & 0.9 & 7.3 & & $\ldots$ & & $\ldots$ \\
\hline Sweden & $3.5^{1}$ & $2.5^{1}$ & $0.6^{1}$ & $10.7^{1}$ & $2.5^{4}$ & & $2.2^{4}$ & ... \\
\hline Switzerland & 3.8 & 2.7 & 0.5 & $14.1^{1}$ & $\ldots$ & $3.7^{2}$ & $\ldots$ & $3.2^{2}$ \\
\hline Turkey & 1.6 & 0.8 & 0.8 & 2.1 & & $\ldots$ & $\ldots$ & $\ldots$ \\
\hline United Kingdom & 2.5 & 1.7 & 0.7 & 11.9 & $\dddot{2}^{2}$ & $\cdots$ & $\cdots$ & $5.4^{1}$ \\
\hline United States & 2.4 & 1.5 & 1.0 & 10.5 & $4.8^{5}$ & $6.5^{5}$ & 3.8 & $4.4^{5}$ \\
\hline Median & 3.1 & 1.9 & 0.8 & 8.7 & & & & \\
\hline
\end{tabular}

$\begin{array}{lc}1 . & 2005 . \\ 2 . & 2004 . \\ 3 . & 2003 . \\ 4 . & 2002 . \\ 5 . & 2001 \\ \text { Source: } & \text { OECD Health Data (2008). }\end{array}$


Table 2. Health services capacity and use, 2006

\begin{tabular}{|c|c|c|c|c|}
\hline & $\begin{array}{c}\text { Physician visits } \\
\text { per capita }\end{array}$ & $\begin{array}{c}\text { Acute care beds Per } \\
1000 \text { population }\end{array}$ & $\begin{array}{c}\text { Average length of } \\
\text { hospital stay (days) }\end{array}$ & $\begin{array}{l}\text { Acute care hospital } \\
\text { days per capita }\end{array}$ \\
\hline Australia & 6.1 & $3.5^{1}$ & $17.2^{1}$ & $1.0^{1}$ \\
\hline Austria & 6.7 & 6.1 & 6.8 & 1.8 \\
\hline Belgium & $7.5^{1}$ & 4.3 & $8.0^{1}$ & $1.2^{2}$ \\
\hline Canada & $5.9^{1}$ & $2.8^{1}$ & $\ldots$ & $0.9^{1}$ \\
\hline Czech Republic & 12.9 & 5.4 & 10.5 & 1.7 \\
\hline Denmark & $7.5^{2}$ & $3.1^{1}$ & 5.3 & $1^{3}$ \\
\hline Finland & 4.3 & 3.1 & $9.9^{1}$ & 0.9 \\
\hline France & 6.4 & 3.7 & 13.2 & 1.0 \\
\hline Germany & $7.0^{2}$ & 6.2 & 10.1 & 1.7 \\
\hline Greece & $\ldots$ & $3.9^{1}$ & $7.8^{2}$ & 1 \\
\hline Hungary & 12.9 & 5.5 & 7.9 & 1.5 \\
\hline Iceland & 6.3 & 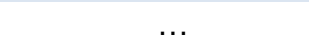 & $\ldots$ & $\ldots$ \\
\hline Ireland & $\ldots$ & $2.8^{1}$ & $7.6^{1}$ & $0.9^{1}$ \\
\hline Italy & $7.0^{1}$ & 3.3 & $7.4^{1}$ & $0.9^{1}$ \\
\hline Japan & $13.7^{1}$ & 8.2 & 34.7 & 2.0 \\
\hline Korea & $11.8^{1}$ & 6.8 & $13.5^{4}$ & $\ldots$ \\
\hline Luxembourg & 6.0 & 4.6 & $\ldots$ & 1.3 \\
\hline Mexico & $2.5^{2}$ & 1.0 & 4.1 & 0.4 \\
\hline Netherlands & 5.6 & 3.0 & $12.5^{5}$ & 0.7 \\
\hline New Zealand & $3.2^{4}$ & $\ldots$ & $6.9^{4}$ & $0.4^{6}$ \\
\hline Norway & $\ldots$ & 3.0 & 7.7 & 0.9 \\
\hline Poland & 6.6 & 4.7 & 7.2 & $1.4^{7}$ \\
\hline Portugal & $3.9^{1}$ & $3.0^{1}$ & $8.7^{1}$ & $0.8^{1}$ \\
\hline Slovak Republic & 10.4 & 4.9 & 9.0 & 1.2 \\
\hline Spain & 8.1 & $2.5^{1}$ & $8.5^{1}$ & $0.8^{1}$ \\
\hline Sweden & 2.8 & 2.2 & 6.1 & $\ldots$ \\
\hline Switzerland & $3.4^{7}$ & 3.5 & 11.3 & 1.1 \\
\hline Turkey & $3.1^{2}$ & 2.5 & 5.1 & $0.4^{7}$ \\
\hline United Kingdom & 5.1 & 2.2 & 8.7 & 0.9 \\
\hline United States & $4.0^{1}$ & 2.7 & 6.4 & 0.7 \\
\hline Median & 6.3 & 3.4 & 8 & 1 \\
\hline 2005. & & & & \\
\hline 2004. & & & & \\
\hline 1999. & & & & \\
\hline 2003. & & & & \\
\hline 2001. & & & & \\
\hline 1997. & & & & \\
\hline 2002. & & & & \\
\hline
\end{tabular}


Table 3. Availability and use of sophisticated medical technologies, 2006

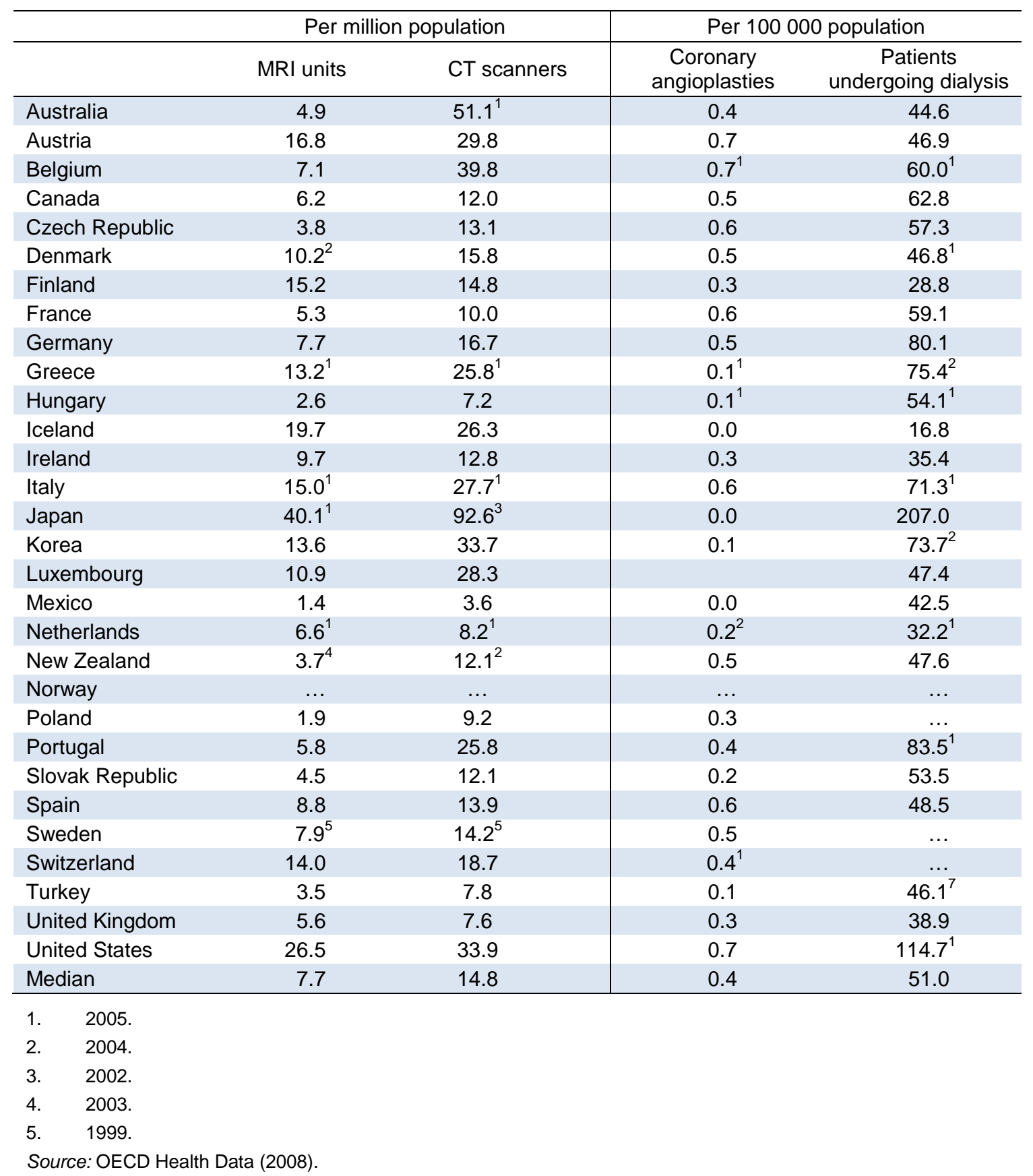

Health expenditures are likely to continue to rise quickly

16. Health expenditures are likely to continue to increase rapidly. The Office of the Actuary in the Centers for Medicare \& Medicaid Services projects that health expenditures will increase from $15 \%$ of GDP currently to $19.5 \%$ of GDP by 2017 (Keehan et al., 2008). Looking further ahead, the Congressional Budget Office projects that health expenditures will increase to $31 \%$ of GDP by 2035 , to $41 \%$ by 2060 , and to $49 \%$ by 2082 (CBO, 2007a). Spending a rising share of income on health, as has occurred in the United States and other developed countries and is likely to continue occurring, makes economic sense as rising incomes increase the relative benefits of investing in health-care consumption to extend life (Hall 
and Jones, 2004); the elasticity of health expenditure per capita (in \$US PPP) with respect to GNI per capita (in \$US PPP) across OECD countries is 1.4, further supporting the view that health-care consumption is a superior good (see Figure 7, second panel). The large and growing size of health spending underscores the importance of ensuring that the sector functions efficiently and equitably.

\section{Efficiency of the health-care system - health status in relation to inputs}

17. While US health spending seems out of proportion to the gains in terms of indicators such as life expectancy, many other factors affect health status, and health expenditure may not have a significant impact on life expectancy, being more relevant for reducing morbidity (Fogel, 2004), which, as noted above, is also an important objective of health-care systems. Joumard et al. (2008) explore other factors that might affect life expectancy at birth using a panel regression of OECD countries. They find that health spending, education attainment, tobacco consumption, alcohol consumption, diet, pollution and GDP all have a significant impact on life expectancy at birth; the same is true for other measures of health status life expectancy at age 65, adjusted premature mortality, and infant mortality - except that diet does not have a significant impact on either adjusted premature mortality or infant mortality. Actual US life expectancy at birth is lower than what is predicted by this model (Figure 8). This suggests that there are other unobserved factors that may influence this health outcome. These might include growing disease prevalence, obesity, or even measurement issues relating to live births. It is also possible that these unobserved factors may reflect a less effective health-care system. However, health expenditure may not be an accurate reflection of resource inputs because, as discussed above, evidence suggests that high spending partly reflects prices rather than quantities of inputs. Joumard et al. (2008) repeated their analysis using health practitioner numbers to proxy resource inputs and data envelopment analysis, and found a somewhat lower relative underperformance of the US health-care system, but also still some unexplained ineffectiveness.

\section{Higher prevalence of costly chronic health conditions in the United States than in other countries}

18. A factor that may help to explain the apparent relative underperformance of the US health-care system is the much higher prevalence of chronic health conditions in the United States than in other countries, at least insofar as this reflects the underlying population health status as opposed to screening rates. Thorpe, Howard, and Galactionova (2007) find that disease prevalence and treatment rates for ten of the most costly conditions ${ }^{11}$ are much higher in the United States than in 10 European countries, based on surveys of the non-institutionalised population aged 50 or over. The much higher obesity rates and higher proportion of this age group that smokes or has smoked in the United States than in the other countries are likely to have contributed to higher prevalence rates of these costly conditions in the United States. Thompson and Wolf (2001) estimate that 5-7\% of total health-care costs in the United States in the late 1990 s could be attributed to obesity, compared with $2-3.5 \%$ in other countries such as Canada, Australia and New Zealand (where data collection methodologies are the same as in the United States). ${ }^{12}$ The cost of health-care services is estimated to be $36 \%$ higher for obese people than for normal weight people in the United States and the cost of medications to be $77 \%$ higher (Sturm, 2002). On the other hand, Angrisano et al. (2007) find that the total US population is not much sicker than the populations in other advanced countries and that this factor accounts for a minor part of the excess in health expenditure in the United States compared with the other countries in their study. ${ }^{13}$ Another factor that contributes to higher US health expenditure levels, but which may improve outcomes, is that the US medical system tends to screen for disease more aggressively than in many other countries and to treat less severe cases of disease (Thorpe, Howard, and Galactionova, 2007). For example, these authors conclude that more intensive screening in the United States contributes to the higher prevalence of (diagnosed) cancer there, but also that mortality rates from cancer tend to be lower. 
Figure 8. Panel regressions: years of life which are not explained by the general model

2003

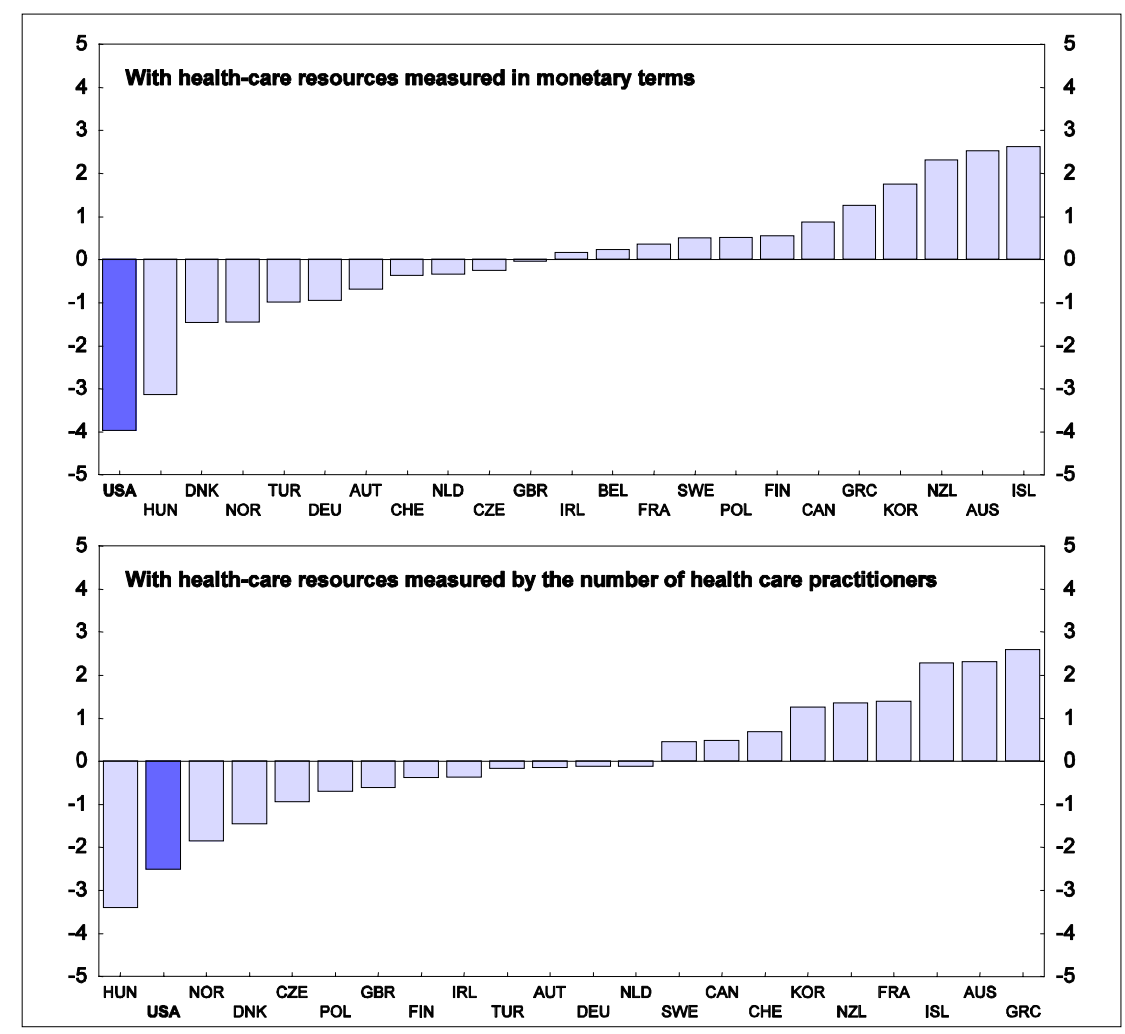

Source: Joumard I., C.André, C.Nicq and O.Chatel (2008), 'Health Status Determinants; Lifestyle, Environment, Health Care Resources and Efficiency', OECD Economic Department Working Paper no 627.

\section{Overutilisation of procedures and technologies}

19. Another issue of concern is the extensive variation in the application of procedures and technologies geographically, for which there does not appear to be any association with health outcomes. The Dartmouth Atlas of Health Care provides extensive data to illustrate the large variations in utilisation of treatments among Medicare beneficiaries. For instance, Skinner, Staiger and Fisher (2006) examine variation in the costs and survival gains across regions in the United States and find that increased spending on the treatment of heart attacks is not associated with comparable increased benefits. This factor may be more important in the United States than in other countries owing to the greater utilisation of new technologies and weaker controls on their use than in systems with single payers.

20. Such findings do not, however, imply that treatments, even new and expensive ones, are globally inefficient. On the contrary, three recent studies suggest that, on average, the increases in associated life expectancy outweigh the costs. Cutler and McClellan (2001) examined the costs and benefits of advances in the treatment of heart attacks and advances in the treatment of low birth-weight babies and concluded that the benefits significantly exceeded the costs. Cutler (2007) updated this work on the technological improvements in revascularisation following a heart attack and found that costs of about $\$ 40000$ were outweighed by the greater than one-year increase in life expectancy, valued at about $\$ 100000$ per year. Likewise, Murphy and Topel (2006) found that the gains from reductions in mortality from investments in medical research and development greatly outweighed the costs, even after allowing for the socially wasteful use of such technologies induced by distorted expost utilisation incentives (arising from the 
prevalence of third-party payer arrangements and the availability of many public and private pension benefits as annuities).

\section{The costs of medical malpractice insurance and of defensive medicine}

21. In the United States, malpractice awards can be enormous, and certainly much greater than in most other countries. This risk encourages physicians to practice defensive medicine, prescribing tests to rule out potential health problems with a low probability of occurring. It also drives up the cost of buying professional liability insurance, ${ }^{14}$ and hence providers' cost of doing business. Based on data for elderly Medicare beneficiaries treated for serious heart conditions in 1984, 1987, and 1990, Kessler and McClellan (1996) found that malpractice reforms that directly reduced provider liability pressure led to reductions of $5-9 \%$ in medical expenditure, potentially reflecting both the practice of less defensive medicine and lower professional liability insurance costs, without substantial effects on mortality or medical complications. They concluded that professional liability reforms do indeed reduce the practice of defensive medicine.

\section{A growing proportion of the population is underinsured}

\section{A growing proportion of the population is uninsured}

22. The United States is one of only three OECD countries - the other two are Mexico and Turkey that do not have universal health insurance coverage. The number of persons without health insurance has increased significantly in recent years, from 38 million (14\% of the population) in 2000 to 46 million (16\% of the population) in $2007 .{ }^{15}$ This increase mainly reflects developments in the non-elderly adult population (aged 18-64), as the number of uninsured children has been broadly stable owing to the expansion of the State Children's Health Insurance Program (SCHIP), ${ }^{16}$ and almost all older people (over 65) are insured with Medicare. The large increase in the number of uninsured adults is largely attributable to employers - particularly smaller ones - being less likely to offer health insurance coverage to their workers (Clemens-Cope and Garret, 2007). ${ }^{17}$ At least three-quarters of the uninsured are not offered health insurance by an employer ${ }^{18}$ (Gruber, 2008). Part-time employees do not generally have access to employer-sponsored health insurance, which would be very costly in relation to their overall labour compensation.

23. The absence of health insurance is much more prevalent among low-income groups than high-income groups (Table 3.4). Some $48 \%$ of households with incomes less than twice the poverty threshold (less than \$40 000) were uninsured at some point during 2007, while for households with higher incomes than this the rate was $16 \%$. The uninsured rate drops steadily as household income rises, to $9 \%$ for households with incomes four times or more the poverty rate. Households with adults who are in fair/poor health and/or have certain chronic health conditions are more likely to be uninsured than healthier adults. Younger adults are more likely to be uninsured than older adults.

24. Rapidly increasing health-care costs have pushed up health insurance premiums and reduced the number of people privately insured, despite the growing risk of being exposed to large losses (Kronick and Gilmer, 1999; Chernew, Cutler, and Keenan, 2005); health insurance premiums increased at an annual average rate of $10.3 \%$ over 2000-2007, while average workers' earnings (excluding non-wage benefits, such as employer contributions to health insurance premiums or costs) only rose at an annual average rate of 3.1\% (The Kaiser Family Foundation and Health Research and Education Trust, 2007). For poorer persons, out-of-pocket premiums represent a considerably higher proportion of household income than for higher-income persons, suggesting that as premiums rise, ever more households are unable to afford them. There is a wide variety of estimates of the proportion of the uninsured population that is able to afford insurance. At the low end, Dubay et al. (2006) estimate that less than one fifth of the uninsured population is able to afford insurance, defining the affordability threshold as household income of $300 \%$ of the federal 
poverty level (annual income in 2004 of $\$ 28935$ for a single person and $\$ 57921$ for a family of four). At this level of income, average premiums ${ }^{19}$ would be about $14 \%$ of income for a single person and $17 \%$ of family income for a family of four, with premiums representing a higher share of income at lower income levels and a lower share at higher income levels. At the high end, Bundorf and Pauly (2006) estimate that almost $60 \%$ of the uninsured in 2000 could afford insurance in the base case, which assumes that insurance is affordable if at least half of the population in similar circumstances is insured, allowing for financial resources, loading ${ }^{20}$ and health status.

Table 4. Adults ages 19-64 who were uninsured or underinsured, by various characteristics

\begin{tabular}{|c|c|c|c|c|c|c|}
\hline \multirow[b]{2}{*}{ Characteristic } & \multicolumn{3}{|c|}{2003} & \multicolumn{3}{|c|}{2007} \\
\hline & $\begin{array}{c}\text { Insured, all } \\
\text { year, not } \\
\text { underinsured } \\
(n=2,031) \\
\end{array}$ & $\begin{array}{l}\text { Underinsured } \\
\qquad(n=310)\end{array}$ & $\begin{array}{c}\text { Uninsured } \\
\text { during the } \\
\text { year }(n=952)\end{array}$ & $\begin{array}{c}\text { Insured all } \\
\text { year, not } \\
\text { underinsured } \\
(n=1,535) \\
\end{array}$ & $\begin{array}{l}\text { Underinsured } \\
\qquad(n=334)\end{array}$ & $\begin{array}{l}\text { Uninsured } \\
\text { during the } \\
\text { year }(n=747)\end{array}$ \\
\hline All adults, millions & 110.9 & 15.6 & 45.5 & 102.3 & 25.2 & 49.5 \\
\hline All adults, percent & $65 \%$ & $9 \%$ & $26 \%$ & $58 \%$ & $14 \%$ & $28 \%$ \\
\hline \multicolumn{7}{|l|}{ Age (years) } \\
\hline $19-29(\%)$ & 51 & 9 & 40 & 41 & 13 & 46 \\
\hline $30-49(\%)$ & 66 & 8 & 26 & 61 & 12 & 27 \\
\hline $50-64(\%)$ & 74 & 11 & 15 & 65 & 18 & 17 \\
\hline \multicolumn{7}{|l|}{ Sex } \\
\hline Male & 67 & 6 & 27 & 61 & 13 & 27 \\
\hline Female & 62 & 12 & 26 & 55 & 16 & 29 \\
\hline \multicolumn{7}{|l|}{ Race } \\
\hline White, non-Hispanic & 70 & 9 & 21 & 60 & 16 & 24 \\
\hline Black non-Hispanic & 54 & 9 & 37 & 51 & 17 & 31 \\
\hline Hispanic & 44 & 9 & 47 & 49 & 6 & 45 \\
\hline \multicolumn{7}{|l|}{ Income $^{1}$} \\
\hline Less than $\$ 20,000$ & 31 & 17 & 53 & 24 & 26 & 50 \\
\hline$\$ 20,000-\$ 39 ; 999$ & 47 & 17 & 35 & 41 & 19 & 41 \\
\hline$\$ 40,000-\$ 59,999$ & 79 & 5 & 16 & 69 & 13 & 18 \\
\hline$\$ 60,000-\$ 99,999$ & 91 & 4 & 6 & 82 & 9 & 9 \\
\hline$\$ 100,000$ or more & 96 & 1 & 2 & 87 & 7 & 6 \\
\hline \multicolumn{7}{|l|}{$\begin{array}{l}\text { Poverty Status } \\
\text { (percent of poverty) }\end{array}$} \\
\hline Under $100 \%$ & 28 & 17 & 55 & 21 & 31 & 49 \\
\hline $100 \%-199 \%$ & 35 & 21 & 44 & 33 & 19 & 48 \\
\hline $200 \%$ or more & 83 & 4 & 13 & 73 & 11 & 16 \\
\hline $200 \%-299 \%{ }^{2}$ & $\ldots$ & $\ldots$ & $\ldots$ & 53 & 16 & 31 \\
\hline $300 \%-399 \%{ }^{2}$ & $\ldots$ & $\ldots$ & $\ldots$ & 70 & 13 & 16 \\
\hline $400 \%$ or more ${ }^{2}$ & $\ldots$ & $\ldots$ & $\ldots$ & 84 & 8 & 9 \\
\hline \multicolumn{7}{|l|}{ Health status } \\
\hline Healthier & 69 & 7 & 24 & 64 & 11 & 25 \\
\hline Sicker $^{3}$ & 57 & 13 & 30 & 50 & 18 & 32 \\
\hline
\end{tabular}

1. In 2003 the categories were "less than \$20 000"; "\$20 000-\$34 999"; "\$35 000-\$59 999", and "\$60 000 or more”.

2. The 2003 survey did not collect income data that were detailed enough to report these poverty groups.

3. Includes adults in fair/poor health, any one of five conditions (high blood pressure, heart disease, lung disease, diabetes, or asthma), or disability. (In 2003 it also included cancer, arthritis, and high cholesterol but not lung disease or asthma).

Source: Commonwealth Fund Biennial Health Insurance Surveys, 2003 and 2007.

25. The uninsured are protected to some extent as hospitals that treat Medicare patients and nonprofit hospitals are obliged to provide medical care to any such person who comes to the emergency room 
with an emergency medical condition ${ }^{21}$ to stabilise it, as well as by the free care provided by hospitals and other providers. If the uninsured are unable to pay for treatment, they can declare bankruptcy and not pay. Hospitals are protected from the costs of treating these uninsured patients. The federal government, through the Medicare and Medicaid disproportionate share adjustments, provides subsidies to hospitals that treat a large number of uninsured individuals. Total payments under these two programmes in fiscal year 2008 exceeded $\$ 18$ billion. Additional subsidy payments to hospitals - including medical education payments and capital payments - are also available to hospitals through the Medicare programme. Moreover, non-profit hospitals (the vast majority of hospitals in the United States) receive tax subsidies in exchange for agreeing to be organised and operated exclusively for charitable purposes. In all, state and federal governments reimburse $85 \%$ ( $\$ 35$ billion in 2004) of the costs of uncompensated care ${ }^{22}$ (Hadley and Holahan, 2004). Herring (2005) finds that these alternatives reduce the purchase of private health insurance coverage.

26. Despite the existence of the safety net and government payments for uncompensated care, uninsured persons receive much less health care than the rest of the population, with adverse consequences for their health. Health expenditures per capita for the uninsured are roughly half of those for the fully insured (Hadley and Holohan, 2004). Uninsured persons are less likely to receive preventative and screening services, less likely to receive appropriate care for chronic conditions, and are more likely to die from cancer, largely because such persons tend to be diagnosed when it is more advanced (Bernanke, 2008; Institute of Medicine, 2002). The uninsured also receive inferior treatment. For example, Doyle (2005) found that uninsured victims of car accidents received $20 \%$ less treatment in hospitals and were $37 \%$ more likely to die of their injuries than the insured. Comparing hospital admissions for "nondeferrable" conditions on either side of the Medicare qualification threshold, Card et al. (2007) found that those who were just over the threshold (and therefore almost all insured) enjoyed significantly more treatment and a $20 \%$ reduction in the 7-day mortality rate than those just under the threshold. Glied and Mahato (2008) finds that differences in rates of insurance coverage between high-and low-wage workers are the main factor accounting for the increasingly large differences in access to health-care services between these two groups (Box 2).

27. The delay in treating the uninsured not only reduces the effectiveness of treatment, as noted above, but also increases costs; insofar as the conditions concerned are communicable diseases, these delays in prevention and treatment also expose the rest of society to health risks. Another factor that unnecessarily raises the costs of treating the uninsured is that they often get treated in emergency rooms for conditions that could have been treated more cheaply elsewhere. ${ }^{23} 24$

\section{An increasing proportion of the population is underinsured}

28. A significant and growing proportion of the population incurs medical costs that are large relative to income as a consequence of requiring health care but being underinsured against medical costs. Schoen, Collins, Kriss, and Doty (2008) estimate that the proportion of the population aged 19-64 that is underinsured has increased from $9 \%$ in 2003 to $14 \%$ in 2007 (see Table 4) $;^{25,26}$ this corresponds to an increase in the proportion of the insured population that is underinsured from $12 \%$ in 2003 to $20 \%$ in 2007. The incidence of underinsurance falls with household income, is higher for sicker households than for healthier ones, and rises with age, reaching $18 \%$ for those aged 50-64. Underinsured adults, as with uninsured adults, experience much greater cost-related problems of access to medical care, tend to delay preventive care screening because of cost, more often do not take treatment for a chronic condition because of cost and have greater care coordination problems. 


\section{Box 2 The gap in health-care services between high- and low-wage workers is widening}

Access to health-care services has declined for low-wage full-time, full-year workers in recent years, whereas it has increased markedly for high-wage full-time, full-year workers ${ }^{1}$. Glied and Mahato (2008) report that low-wage workers were less likely to visit a physician in 2003 than in 1996, less likely to have a regular source of care, to have made only small improvements in terms of receiving basic preventive services and in some cases (blood pressure checks) to have received fewer services. High-wage workers, by contrast, enjoyed increases across all of these service dimensions, raising the already large gap that existed in 1996 between the services they received and those received by low-wage workers. Average annual health-care expenditures by high-wage workers nearly doubled between 1996 and 2003, whereas for low-wage workers the increase was only 14\%. Such expenditures for high-wage workers are now almost double the level for low-wage workers (Figure 9). High-wage workers are more likely to report being in good health than are low-wage workers.

Figure 9. Average annual health-care expenditures, by wage status

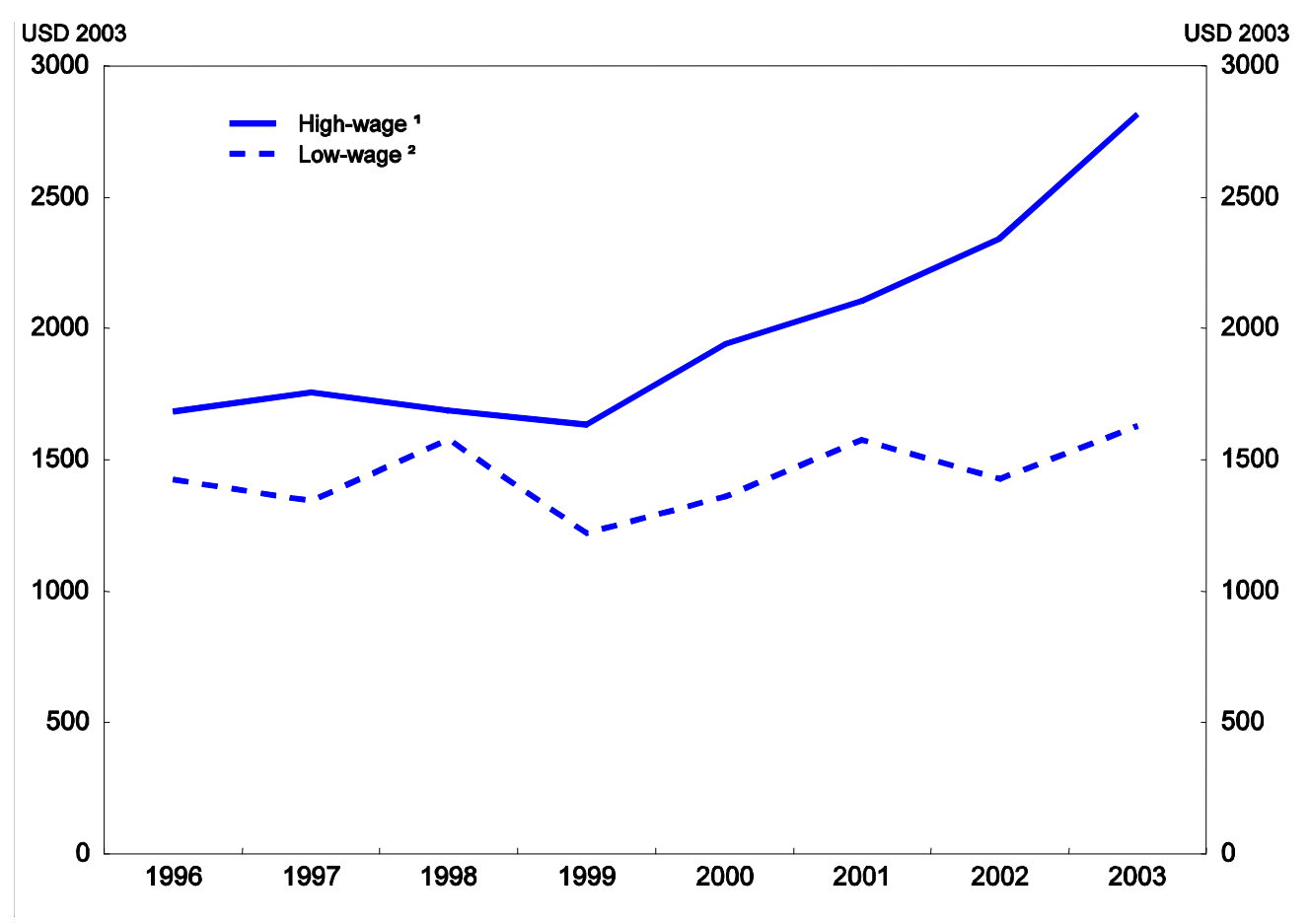

1. Top $20 \%$ of the wage distribution.

2. Bottom $20 \%$ of the wage distribution.

Source: Glied and Mahato (2008).

The main factor driving up health-care costs for high-wage workers appears to be that they are given much greater access to new medical technologies than are low-wage workers. Glied and Mahato (2008) cite the example of newer drugs, which are associated with higher rates of survival. The proportion of prescription drugs that were less than 20 -years old rose from $17 \%$ in 1996 to $23 \%$ in 2003 for high-wage workers, whereas the increase for low-wage workers was only from $13 \%$ to $15 \%$.

Many, though not all of the gaps in access to health care described above disappear once differences in the rates of health insurance coverage between high- and low-wage workers are controlled for. In this regard, Glied and Mahato (2008) find that the proportion of full-time, full-year workers without insurance coverage increased from $22 \%$ to $31 \%$ in the bottom quintile of earnings between 1996 and 2003 but was stable at $6 \%$ in the top quintile of earnings. Moreover, a much higher proportion of low-wage households have high out-of-pocket expenses for health care in relation to income than is the case for high-wage households, and this gap has increased in recent years.

1. Low-and high-wage workers correspond to workers in the bottom and top quintiles of earnings, respectively. 
29. Schoen, Collins, Kriss, and Doty (2008) also found that the "underinsured were more likely to report benefit limits, including limits on the total dollar amount a plan would pay for medical care and on the number of yearly visits to doctors, and were less likely to report dental or prescription drug benefits" than the insured population that was not underinsured; total dollar limits on benefits limit the usefulness of insurance in protecting against major financial risks from medical costs. Despite benefit limits and higher deductibles, the underinsured reported paying premiums similar to those paid by the more adequately insured population. A factor contributing to this apparent anomaly is that the underinsured are less likely to have employer-sponsored insurance and are therefore more likely to buy coverage through the individual market, where insurance is more expensive. Insurance is more expensive (i.e., load factors - the proportion of premiums not going to pay medical claims - are higher) in the individual (and small group) market because adverse selection risks and administrative costs are higher than in the employer-sponsored market and because there is also a larger risk premium to compensate for greater variance in medical expenditures over time.

\section{Reforms to extend health insurance coverage}

\section{Market failures in the health insurance market}

30. Imperfect information results in two main market failures in the private health insurance market. First, insurers are not fully informed about an applicant's characteristics that affect the expected value of future claims. This exposes the insurer to the risk that someone wants to buy health insurance because they are a bad risk. To reduce exposure to losses from this risk, known as adverse selection, insurers invest in obtaining information about the applicant's true characteristics and adjust premiums accordingly or refuse to offer insurance. Second, insurers lack information about the future behaviour of the individual. Insurance increases incentives to behave in ways that increase claims, notably by consuming more medical services than otherwise. To limit this risk, known as moral hazard, insurers propose policies with lower premiums that have more cost sharing (deductibles, copayments, or coinsurance). ${ }^{27} 28$

31. Adverse selection risk can be overcome by constituting large pools of persons to be insured that are independent of individuals' risk characteristics. In the private health-care insurance market in the United States, such pools are mainly employment based. The fact that insurers do not have to invest in obtaining information to avoid bad risks is a major factor underlying the lower administrative costs for insurance of large employment-based pools than of individuals or small groups: loading charges range from 5-8\% of benefits for large groups (more than 1000 employees), to $15-20 \%$ of benefits for mediumsized groups (100-200 employees) and 60-80\% of the benefits for individual policies, although some of these differences also reflect the more comprehensive cover obtained by large firms (fixed distribution costs spread across more medical benefits) (Phelps, 2002) ${ }^{29}$ In almost all other OECD countries, adverse selection (at least for primary health insurance) is overcome by creating universal entitlements, making the pool the country's entire population.

32. While the dominance of employer-based health insurance emerged in the United States mainly owing to an historical accident, government has supported these arrangements through the "tax exclusion", so called because labour compensation in the form of health insurance benefits is not treated as income subject to personal income or payroll taxation (Box 3), as well as through the Employee Retirement Income Security Act of 1974 (ERISA), which exempts employee benefit plans from various state insurance regulations (mandates). Although the tax exclusion plays a valuable role in supporting the constitution of large insurance pools, it also has some drawbacks. In particular, it is an open-ended subsidy that encourages the purchase of policies that have little cost sharing, accentuating moral hazard risks. It has this effect because employer-sponsored health-care insurance policies are purchased out of pre-tax income whereas out-of-pocket payments are made out of net-of-tax income. This factor is estimated to reduce the cost of health-care insurance by about $35 \%$ relative to the cost of out-of-pocket payments (and other goods 
and services purchased out of net-of-tax income) for a typical worker (Gruber, 2008) ${ }^{30}$ Partly in response to these incentives, approximately $87 \%$ of health-care spending is paid through insurance, while the remaining 13\% comes from out-of-pocket payments (Figure 10). The share of out-of-pocket expenses in total health-care expenditure in the United States is relatively low by international comparison (the median among OECD countries is $18 \%){ }^{31}$

Figure 10. Out-of-pocket expenses as a share of total healthcare expenditures ${ }^{1}$

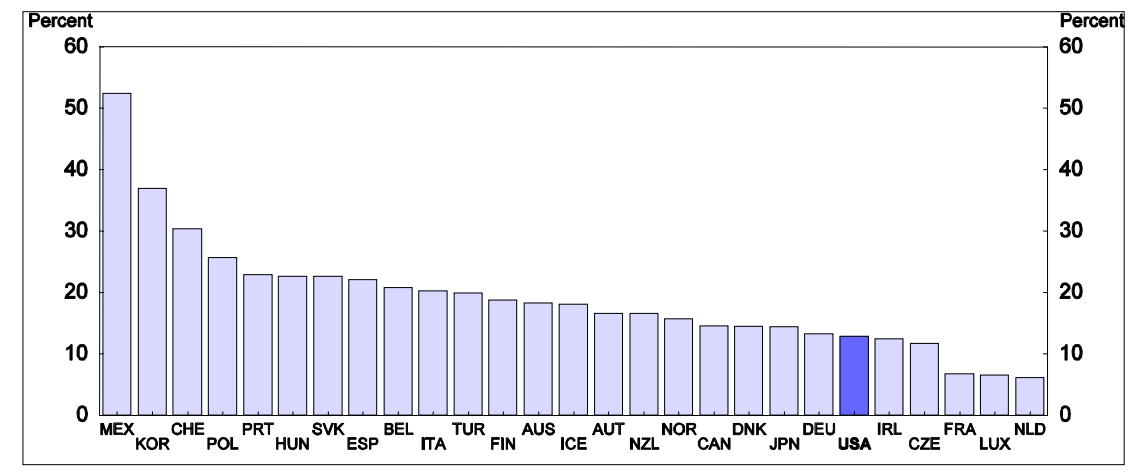

1. 2006, except for Australia, Slovak Republic, Turkey and Japan: 2005.

Source: OECD Health data (2008).

\section{Box 3. The origins and budget cost of employment-based health insurance}

The predominance of employment-based health insurance in the United States is unique amongst OECD countries: even in the Netherlands and Switzerland, where residents also obtain (primary) health insurance from private insurers rather than from a single payer (as in most other countries), such insurance is not predominantly employment based but rather mainly purchased in the individual market. The situation in the United States largely results from an historical accident: wage controls instituted during the second-world war led to a proliferation of nonwage benefits. A subsequent IRS ruling made them exempt from payroll and income taxes, making this form of remuneration attractive even after the wage controls were rescinded. A provision in the Stabilization Act of 1942, which limited the wage increases that employers could grant, permitted employer-paid health insurance to be provided as a fringe benefit exempt from wage controls. The preference was extended to the tax code shortly thereafter. Under a 1943 administrative tax-court ruling and 1954 changes to the Internal Revenue Code, employer contributions to employees' health-insurance costs became deductible to the employer and non-taxable to the employee (Cogan et al, 2005).

Today, approximately 164 million non-elderly persons receive health insurance benefits from their employer, while only 16 million purchase private insurance directly themselves. The tax exclusion cost the federal budget $\$ 200$ billion in 2004 (Final Report of the President's Advisory Panel on Tax Reform, 2005; the tax exclusion probably amounts to about $\$ 225$ billion in 2008) and is rising at the same rate as health-care expenditures (i.e., considerably faster than GDP).

33. The effect of benefit designs with little cost sharing on consumption of health-care services was documented in the RAND Health Insurance Experiment in the early 1980s, in which individuals were randomly assigned to insurance plans with different levels of enrolee cost sharing up to annual costs of $\$ 1000$ (at 1984 prices), beyond which all costs were covered by insurance (Manning et al., 1987). The experiment showed that the amount of health-care consumption varied inversely with the level of cost sharing. For instance, enrolees placed in the plan with no cost sharing spent $\$ 777$ for the year, while enrolees placed in the plan with a $25 \%$ coinsurance rate spent $\$ 630$ for the year. Despite these different levels of spending, there were no significant differences in the health outcomes of these two groups except for low income and unhealthy individuals, who had worse health outcomes in the group with higher cost sharing. The elasticity of medical care use with respect to its price in this study was -0.2. Based on this low 
elasticity, Feldman and Dowd (1991) estimate that the deadweight loss due to moral hazard in employer-sponsored health insurance was $\$ 33.4$ billion- $\$ 109.3$ billion in 1991 , equivalent to $4 \frac{1}{2}$ per cent$14 \frac{1}{2}$ per cent of total health-care expenditures at the time.

34. The tax exclusion also raises equity concerns. It violates vertical equity, as the subsidy rises with income, as well as horizontal equity, as the subsidy results in different taxation of two individuals with identical incomes and circumstances except that one benefits from employer-sponsored-health insurance and the other does not. As noted above, most of the underinsured, who tend to have lower incomes, cannot benefit from this subsidy as they are not even offered such insurance.

\section{Reforms to expand insurance coverage and to improve health outcomes in relation to health costs}

35. An expansion in access to health-care services for lower-income Americans may facilitate achievement of the US federal government's health goals laid out in Healthy People 2000 - to reduce and ultimately eliminate health inequalities amongst various segments of the population and to increase life expectancy and quality of life for Americans of all ages, as noted above. Insofar as financial access to health-care services becomes less unequal, some improvement in population health status in relation to health expenditures could also be expected, given diminishing returns to health expenditures at any point in time (i.e., with unchanged technology).

36. One approach to advancing these objectives would be to create a pooling mechanism in the individual market to reduce adverse selection risks, which currently contribute to high load factors (owing to high underwriting costs aimed at weeding out bad risks) in the individual and small-group health insurance markets, reducing the attractiveness of such insurance. Such a pooling mechanism could be provided by creating geographically-based health exchanges or a national exchange subject to a number of regulations, such as requiring insurers to offer policies on a guaranteed-issue- and community-rated basis through the exchange, to prevent adverse selection from concentrating all the bad risks in the exchange. A risk equalisation fund could compensate insurers for enrolees with predictably high medical expenses. Adverse selection risks could be reduced further by introducing a requirement (mandate) for individuals to be insured. This would expand the risk pool, notably by encouraging younger, healthier individuals to buy insurance. For a requirement to be insured to be enforceable, it would be necessary to provide subsidies for lower-income persons to buy health-care insurance as many of them could not otherwise afford to comply. Such subsidies could be financed by eliminating the tax exclusion. Provided that the subsidies are provided in a way that is independent of the choice of health plan, financing them in this way would reduce incentives to buy policies with little cost sharing, thus tackling moral hazard, and would make government measures to support the purchase of health insurance more equitable. While reforms along these lines could help to improve the relationship between the health status of the US population and health-care expenditures, such reforms would not, however, reduce the high long-run rate of growth in health expenditures, which many consider to be another weakness of the US health-care system. Indeed, by expanding insurance coverage, such reforms could even cause a step-up in health expenditures. Also, the drawbacks of a requirement to be insured should not be underestimated, including: the complexity of defining the required coverage; the risk that this requirement will become unduly inflated; the inherent reduction in consumer choice; and difficulties in designing and implementing appropriate enforcement mechanisms.

37. Gruber (2008) reports results from a micro-simulation model of the effects of a reform package along these lines; the specific details of his package are spelled out in Box 4, including the means-testing of subsidies for the purchase of health insurance. Such a package is assumed to reduce the uninsured population by 45 million, essentially achieving universal coverage (Table 3.5, Column 3 ). The population covered by employer-sponsored insurance would shrink by 24 million (15\% of the base population). ${ }^{32}$ This contraction, which no longer matters as individuals have access to the new insurance pool, along with takeup by the uninsured accounts for most of the increase in the size of the new insurance pool ( 78 million). 
The reform package would yield a fiscal surplus of $\$ 50$ billion assuming that the tax exclusion costs $\$ 200$ billion. It would also cause a large redistribution of federal government policy benefits towards low-income households from the rest of the population - households with incomes of $300 \%$ of the poverty level or more would lose federal benefits from this reform. The $\$ 50$ billion surplus could be returned to households up to the median income level to ensure that none of them is made worse off by the reform, as is illustrated in the fourth column of Table $5 .{ }^{33}$ Such a measure would increase the political viability of the reform package.

Box 4. The health-insurance reform package in Gruber's (2008) micro-simulation
Low income individuals not entitled to enrol in existing public insurance programmes and without access
to employer-sponsored insurance are enrolled in new state-specific pools. Insurers can only offer
insurance in these pools on a guaranteed issue, community-rated basis. There is redistribution across
plans within this pool to offset very high cost cases. Low-income individuals offered employer-sponsored
insurance can join the pools provided that they bring with them their employer's contribution.
The benefits package within the pools varies based on income, from complete coverage with minimal
cost sharing for persons with incomes below the poverty line to more cost sharing at higher incomes.
Selective provider networks are used.
Subsidies limit the share of income that individuals must pay for these insurance policies. These shares
of income range from $2 \%$ between $100 \%$ and $150 \%$ of the poverty line (approximately $\$ 20000-\$ 30000$
per year) up to $12 \%$ of income between $350 \%$ and $400 \%$ of the poverty line, which roughly corresponds
to median income in the United States. Beyond this income level, there are no more subsidies.
An individual requirement (mandate) to have health insurance cover is introduced with dissuasive
penalties for non-compliance - it is assumed that $97 \%$ of the uninsured obtain insurance cover.
The subsidies are financed by removing the tax exclusion for employer-sponsored health insurance
benefits.

38. A reform package with a pooling mechanism, mandate and subsidies for low-income persons to buy insurance in the individual market was recently implemented in Massachusetts, the main differences being that dissuasive penalties for not having insurance cover are only being phased in progressively in Massachusetts and that, naturally, the federal tax exclusion remains in place (Box 5). Indeed, the Massachusetts reform package extends the tax exclusion to individuals who work for an employer that does not offer health insurance and therefore must buy insurance on their own by creating a mechanism that allows such insurance to be purchased out of pre-tax income. ${ }^{34}$ The first year of experience of the Massachusetts reform showed some promising results. As of May 2008, about 350000 residents $-5.5 \%$ of the state's population - were newly insured, leaving approximately $4 \%$ of the population uninsured. About half of the newly insured - far more than the State expected - were enrolled in Commonwealth Care, a subsidised insurance programme for adults who earn no more than $300 \%$ of the federal poverty guidelines, while about a third had purchased private insurance or gained employer-sponsored coverage. Because of higher than anticipated enrolment, the State is facing a funding shortfall that it had not anticipated. It should also be borne in mind that the Massachusetts experience may not be indicative of what the US experience would be as Massachusetts is more affluent and had a lower uninsured rate than the national average. 
Table 5. New insurance pool for individuals and small groups with subsidies and changed tax exclusions

\begin{tabular}{|c|c|c|c|c|}
\hline Tax exclusions & None & None & Eliminate & Distributionally \\
\hline & & & All & Neutral \\
\hline Individual mandate & No & Yes & Yes & Yes \\
\hline Voucher & Yes & Yes & Yes & Yes \\
\hline \multicolumn{5}{|c|}{ Changes in population (millions of persons) } \\
\hline Uninsured take-up & 25 & 33 & 34 & 34 \\
\hline Uninsured share of take-up (\%) & 48 & 53 & 43 & 43 \\
\hline Uninsured increase & 2 & 0 & 0 & 0 \\
\hline Net decrease in uninsured & 23 & 45 & 45 & 45 \\
\hline Net change in employer insured & -16 & -7 & -24 & -24 \\
\hline Net change in non-group insured & -7 & -7 & -7 & -7 \\
\hline Net change in publicly insured & -7 & -3 & -3 & -3 \\
\hline Net change in new pool & 53 & 62 & 78 & 78 \\
\hline \multicolumn{5}{|l|}{ Costs } \\
\hline Total cost (USD 2006 millions) & 101,900 & 124,100 & $(50,000)$ & $(14,500)$ \\
\hline Cost per newly insured (USD 2006) & 4,400 & 2,700 & $(1,100)$ & $(400)$ \\
\hline \multicolumn{5}{|c|}{ Targeting } \\
\hline Average age of newly insured & 32 & 31 & 31 & 31 \\
\hline Newly insured fair/poor health (\%) & 10 & 10 & 10 & 10 \\
\hline $\begin{array}{l}\text { Average cost of newly insured (USD } \\
\text { 2006) }\end{array}$ & 3,400 & 3,400 & 3,400 & 3,400 \\
\hline $\begin{array}{l}\text { Spending per } \$ \text { of insurance (USD } \\
2006 \text { ) }\end{array}$ & 1.10 & 0.81 & $(0.33)$ & $(0.10)$ \\
\hline \multicolumn{5}{|c|}{ Distribution of federal policy benefits (USD 2006 billions) } \\
\hline$<100 \%$ poverty & 50 & 63 & 63 & 63 \\
\hline $100-200 \%$ poverty & 39 & 49 & 42 & 43 \\
\hline $200-300 \%$ poverty & 14 & 20 & 0 & 0 \\
\hline $300-400 \%$ poverty & 1 & 2 & $(28)$ & 0 \\
\hline $400-500 \%$ poverty & (1) & $(0)$ & (28) & $(21)$ \\
\hline$>500 \%$ poverty & (3) & $(2)$ & $(87)$ & $(87)$ \\
\hline
\end{tabular}

Source: Gruber, J. (2008), "Covering the uninsured in the U.S.", NBER Working Paper No. 13758.

\section{Box 5. Massachusetts health-insurance reform}

The main elements of the health-insurance reform enacted in 2006 are the following:

- A legal requirement (mandate) for all state residents to purchase health insurance coverage as of 1 July 2007. Penalties for non-compliance were loss of the personal deduction (\$219) on state income tax in 2007 , rising to $50 \%$ of the average cost of a health insurance plan in the geographic region in which the person lives for 2008 and beyond, up to a maximum of $\$ 912$. Two per cent of the population is exempt from this legal requirement because insurance coverage has been deemed not to be affordable for them.

- A legal requirement (mandate) for employers with 11 or more employees to make a "fair and reasonable" contribution towards health insurance coverage for their employees or pay a "Fair Share" contribution since 1 July 2007. These employers must also offer a Section 125 "cafeteria plan" to employees that enables them to purchase health insurance with pre-tax dollars.

- Expansion of Medicaid (MassHealth) to cover children in families with incomes up to $300 \%$ of the federal poverty level.

- $\quad$ Creation of a new programme (the Commonwealth Care Health Insurance Program, or CommCare) that provides subsidized health insurance coverage for persons with incomes below $300 \%$ of the federal poverty 


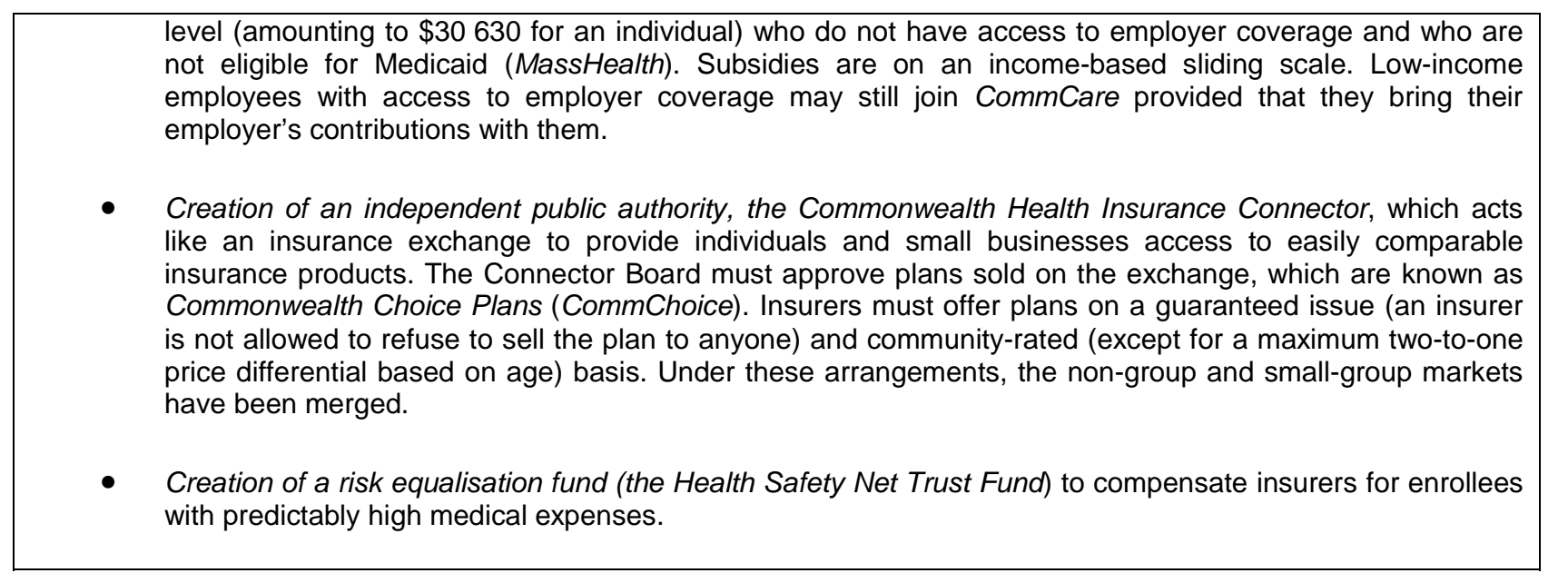

39. In addition to helping to make progress towards the US government's health objectives for the nation and improving the relationship between health outcomes and health-care expenditures, the reforms put forward here have a number of other advantages. First, they are incremental, building on the dominant role of private insurers for the non-elderly population, not radical, as would be moving to single-payer arrangements, which are found in most other OECD countries. Second, they are fiscally neutral, as demonstrated by Gruber's simulations. Third, they appear to be in the mainstream of reform plans in the public domain, sharing important features of the plans put forward by the 2008 Democratic Presidential candidate (health-insurance exchange, subsidies for low-income persons) and the 2008 Republican Presidential candidate (removing the tax exclusion) ${ }^{35}$. These reforms do not preclude expanding insurance coverage to certain target groups through an extension of Medicaid or Medicare. The option of increasing insurance coverage through these public plans was already recommended in the 2002 OECD Economic Survey of the United States and remains valid. ${ }^{36}$ Nevertheless, political support for such a reform appears to be weak at the moment, underlining the importance of other reform fronts where it may be more feasible to make progress. On the other hand, such reforms could lead to an increase in health expenditure. ${ }^{37}$ The withdrawal of subsidies in the individual health income market as income rises would also increase marginal effective tax rates, leading to a reduction in total hours worked. Similarly, abolition of the tax exclusion would increase income tax rates for persons in employer-sponsored schemes, also reducing work incentives. ${ }^{38}$

\section{Medicare reforms to improve value for money}

40. Public spending on the Medicare programme for the elderly (and the disabled, who represent a small minority of enrolees) has generally increased more rapidly than total health-care expenditures since its creation in 1965; Medicare outlays have increased from around 15\% of total health care expenditures in 1980 to $19 \%$ in 2006, representing approximately 3\% of GDP. While population ageing accounts for some of the increase - the 65 or over age group has been growing faster than the rest of the population expenditure per person has also been increasing faster than for the rest of the population. Two recent policy changes have boosted Medicare spending. The first is the Medicare Part D prescription drug benefit in 2006 as the result of the 2003 Medicare Modernization Act (MMA).$^{39}$ About three quarters of spending on the prescription drug benefit is financed through general tax revenues. The second is the expansion of private Medicare Advantage (MA) plans, which also resulted from the 2003 MMA.

41. The Office of the Actuary in the Centers for Medicare \& Medicaid Services (CMS) projects that total Medicare spending will rise to $10.8 \%$ of GDP in 2082, implying only a slightly higher rate of increase than in total health-care expenditures, which are projected by the CBO (2007b) to rise from 15\% of GDP in 2006 to $49 \%$ of GDP in 2082. From these projections it can be deduced that population ageing as such is 
not the dominant influence on the projected growth in Medicare expenditures. ${ }^{40}$ Rather, the factors that are driving health-care expenditure in general higher are having the same effect on Medicare outlays. The main driver of higher health-care expenditure appears to be the introduction of new technologies (Newhouse, 1992), which, as discussed above, seem to be worthwhile as the improvements in life expectancy and in the quality of life that they yield on average are more valuable than the cost of the technologies. Even so, financing these increases in expenditure (as well as in expenditure on Medicaid, which is currently about three quarters of the size of Medicare expenditure) is a major challenge for government. An immediate increase in the combined Part A payroll tax from $2.9 \%$ to $6.4 \%$ would be necessary to achieve solvency over the 75-year window. About half of total federal Medicare spending is financed by the payroll tax, so there would have to be an associated increase in general tax revenues for Parts B and D of Medicare. In the absence of increased tax revenue, either spending on non-health items or in Medicare itself would have to be reduced.

42. While there may not be much that can or should be done to slow the long-term growth of Medicare expenditures, a variety of measures could be taken to reduce costs without having any adverse effect on the quality of health-care services available to enrolees. One compelling piece of evidence, as noted above, is based on data drawn from the Dartmouth Atlas of heath care, which shows that Medicare health-care spending per capita varies widely across the United States without associated variation in health outcomes. Providers in some regions of the country have practice styles that are more aggressive and costly, and that do not appear to provide significant benefits in terms of patients' health outcomes. Extrapolating these potential efficiency gains to the whole country indicates that Medicare spending could be reduced by as much as $30 \%$ without hurting the health status of the population. Policy settings should be changed to encourage best practice.

\section{Create a Comparative Effectiveness Institute}

43. The establishment of a Comparative Effectiveness Institute outside of the federal government could be a useful step to help achieve greater efficiency; similar agencies (operating within the government) exist in the United Kingdom, Australia, Canada, and Germany. A Comparative Effectiveness Institute would conduct and/or coordinate large-scale cost-effectiveness studies on medical treatments and disseminate the results to both insurers and providers. Promoting the use of the least costly effective treatment that is appropriate for a patient could yield considerable savings in total health-care expenditures given the findings of the Dartmouth Atlas study quoted above, particularly if providers have incentives to do so. One option for promoting the use of such treatments by Medicare patients would be for the Medicare Payment Advisory Commission (MedPAC) to issue specific guidelines about which services are actually covered by Medicare, while another option would be to use the cost-effectiveness findings to determine the copayments for various services (i.e., lower copayments for more cost-effective and appropriate treatments and higher copayments for less cost-effective and less appropriate treatments). Such a mechanism would certainly strengthen incentives to develop cost-saving technologies. It would also, however, represent a radical departure from Medicare policy of providing coverage for services that are medically effective and appropriate irrespective of cost. Pedagogy would be required for the American public to accept that cost is a relevant factor in determining what an appropriate treatment is for any given patient. It would also have to be structured in such a way as not to restrict access to innovative medical technologies, as is sometimes claimed to have occurred at similar entities in other countries.

44. A secondary benefit from establishing an independent Comparative Effectiveness Institute in this manner might be to better establish a system for determining Medicare benefits that is less subject to interference from Congress. For instance, the MedPAC makes recommendations each year for improving the efficiency and equity of payments to providers that are usually ignored by Congress. Finding political support for the creation of the Institute would not be easy, however. There was strong opposition to similar arrangements in the past in the United States. 
ECO/WKP(2009)6

\section{Decrease the generosity of supplemental Medicare insurance designs for beneficiaries without chronic conditions to reduce moral hazard risks}

45. Medicare pays physicians under the Original Medicare Plan, which is a fee-for-service plan to which most Medicare enrolees belong, according to a fixed schedule of fees. Although Medicare reimbursements come with notable out-of-pocket payments, about $90 \%$ of Medicare beneficiaries have supplemental insurance covering them (such as employer-sponsored supplemental coverage, Medigap and Medicaid) that insulates them from cost-sharing provisions. In addition, the assignment of supplemental benefits directly to the provider of service reduces price transparency and makes the patient insensitive to price signals, a situation that has been shown to alter consumer behaviour and reduce the elasticity of demand to prices (CBO, 2008). The CBO traditionally estimates that Medigap policyholders use at least $25 \%$ more services than Medicare enrolees who have no supplemental coverage, although this has been criticized for being an overestimate by a recent empirical study (Lemmieux et al, 2008). Another study shows that elderly patients are quite price sensitive in their health care consumption: a $10 \%$ increase in price is associated with a $14 \%$ decline in utilisation of physician visits, a far greater effect than that found in the RAND study, which did not cover the elderly (Chandra et al. 2007). This would argue for decreasing the generosity of supplemental Medicare insurance benefit designs to reduce moral hazard risks. The above study also shows, however, that the saving from reduced physician visits and pharmaceutical consumption is partly offset by greater use of hospitalisation, notably among chronically-ill patients. Hence, while less generous supplemental insurance might yield more efficient health insurance for some patients, the opposite holds for chronically-ill patients, who should not be deterred from seeing the doctor and buying prescribed drugs for their chronic condition. While less generous supplemental insurance-benefit designs for Medicare beneficiaries without a chronic health condition would yield some savings, they would not be large as this group only represents $18 \%$ of Medicare beneficiaries and a subset of these is dually eligible for Medicaid.

\section{Reduce overpayments to Medicare Advantage}

46. Medicare Advantage (MA) plans (also known as Medicare Part C) provide Part A (hospital) and Part B (medical) coverage as well as medically-necessary services. They are often managed plans (like HMOs or PPOs). These plans generally offer more services, such as prescription drug coverage, than the Original Medicare plan and tend to have less cost sharing. Unfortunately, these plans have proved to be more expensive than the cost to Medicare of providing these services directly. The nonpartisan Congressional MedPAC organisation estimates that these plans receive payments that are $13 \%$ higher than the payments to providers under the traditional fee-for-service Medicare programme for similar beneficiaries (MedPAC, 2008); fee-for-service MA plans are estimated to cost $17 \%$ more than the cost of Medicare providing the same benefits itself. According to MedPac, a significant portion of these extra payments goes to fund plan administration and profits and not to services for beneficiaries. MedPac also notes that the extra payments raise equity concerns as they are funded by all Medicare Part B beneficiaries (through their Part B premiums) and by all taxpayers (through general revenues) while only MA enrolees benefit, although it should be noted in this regard that almost all Medicare beneficiaries have the opportunity to join a MA plan. In addition, such payments enable MA plans to attract new clients without improving efficiency, a problem underlined by the rapid growth in fee-for-service plans. A start to overcoming these problems was made in recent legislation, which reduced payments to MA plans and required most fee-for-service MA plans to form provider networks; the savings were used to avoid implementing a programmed reduction in physicians' fees (Box 6). 


\section{Box 6. The Sustainable Growth Rate mechanism to control growth in Medicare expenditure on physicians' services and related services}

In view of repeated overruns in payments to physicians, Congress established in 1998 a new mechanism called the "sustainable growth rate" (SGR) aimed at controlling payments made for physicians' services and in connection to visits to physicians (such as laboratory tests and drugs administered by physicians). ${ }^{1}$ The goal was to subject aggregate payments to a ceiling. Under the SGR mechanism, fees paid to physicians are adjusted downward if the pre-established spending ceiling is exceeded or upwards in the opposite situation. Left unaltered, the SGR formula ultimately recoups spending that exceeds the cumulative target by reducing payment rates for physicians' services or by holding increases below inflation. Five years after the SGR was established, spending overruns triggered the SGR mechanism to demand a cut in doctors' fees of $5.4 \%$, which was approved by Congress. Subsequent overruns of ceilings should have again triggered cuts in physician payment rates but, in the face of opposition, these were averted by the adoption of legislative action that allocated additional spending to override cuts in the doctors' fee schedules. A cut in doctors' fee schedule of $10.6 \%$ was to take place on 1 July 2008 to begin recouping these slippages. This was strongly opposed by physicians, who said that this would cause doctors to limit the number of new Medicare patients that they see (AMA, 2008). In reaction, legislation was proposed to avoid cuts in payment rates, with funding taken from cuts in federal payments to the Medicare Advantage programme. Despite a Presidential veto, a large enough majority was achieved in Congress to pass this Bill into law.

1. A similar mechanism operates in Germany.

\section{Use competitive tenders for purchases of medical equipment and supplies}

47. Medicare pricing policy for medical equipment could be reformed to produce cost-saving gains. Current policies dictate that Medicare use fee schedules primarily based on historical charges. The Government Accountability Office (GAO) has established that Medicare has paid higher than market rates for medical equipment and supplies provided to beneficiaries under Medicare Plan B (GAO, 2008). The Balanced Budget Act of 1997 required that Medicare administrators test competitive bidding as a new way to set payments. This test was administered in two locations in which suppliers could compete on the basis of price and other factors for the right to provide their products. The results were that a competitive bidding programme would reduce payments by $26 \%$ on average, based on strict criteria of product quality and security of suppliers, and without significantly reducing access of beneficiaries to supplies. Anecdotal information also suggests that Medicare pays much higher prices than charged by retail outlets for the same products. If competitive bidding were extended, it could save Medicare \$1 billion a year. While competitive bidding was to have been spread to 70 more locations soon, the new law recently passed by Congress that avoided a cut in physicians' fees and reduced payments to Medicare Advantage also delayed the generalisation of competitive bidding until 2009. It is important that there be no further delays in the implementation of this cost-saving measure.

\section{Box 7. Recommendations for improving value for money and insurance coverage in health care}

\section{Reforms to increase health insurance coverage and encourage more cost-conscious purchasing}

Reform the individual and small-group market to facilitate greater pooling. One approach to doing this would be to increase the size of risk pools and reform these markets by requiring community-rated and guaranteed-issue policies, thus disconnecting premiums from individual health risks. Such reforms would tend to reduce adverse selection, resulting in lower premiums on average in relation to the actuarial value of policies, making health insurance in these markets more attractive. This approach would have a greater impact if accompanied by a requirement to be insured, although such a requirement would have its own drawbacks, such as the complexity of defining the required coverage and the risk that this requirement could become inflated.

Provide income-related subsidies for the purchase of insurance that are unrelated to the choice of plan to lowand middle income persons not offered health insurance by their employer so that they are able to afford such 
insurance and finance these subsidies by eliminating the tax exclusion (i.e., the exclusion from taxable personal income and payroll tax of compensation paid in the form of health insurance cover). Financing the subsidies in this way would have the advantage of removing incentives inherent in the tax exclusion to buy plans with little cost sharing, thus facilitating more cost-conscious purchasing decisions.

\section{Medicare reforms to improve value for money}

Create a comparative effectiveness institute outside of the federal government to conduct and/or co-ordinate cost-effectiveness studies and use those results to decide how services would be covered or reimbursed by Medicare. These arrangements would need to be structured in such a way as not to restrict access to innovative medical technologies that are cost effective.

Decrease the generosity of supplemental Medicare insurance designs for beneficiaries without chronic conditions to reduce moral hazard risks, which supplemental insurance accentuates by insulating Medicare beneficiaries from Medicare's cost-sharing provisions.

Gradually lower Medicare Advantage (MA) payments to the level for traditional fee-for-service Medicare plans, thereby increasing the pressure on insurers to improve efficiency to attract new clients.

Do not delay further the use of competitive tenders for purchases of medical equipment and supplies.

\section{Notes}

1. It has been claimed (Ohsfeldt and Schneider, 2006) that adjusting for the higher death rate from accident or injury in the United States over 1980-99 than the OECD average would increase US life expectancy at birth from 18th out of 29 OECD countries to the highest. In fact, what the panel regression estimated by these authors shows is that predicted life expectancy at birth based on US GDP per capita and OECD average death rates from these causes is the highest in the OECD. The adjustment for the gap in injury death rates between the United States and the OECD average alone only increases life expectancy at birth marginally, from 19th among 29 countries on average over 1980-1999 to 17th. Hence, the high ranking of adjusted life expectancy at birth mainly reflects high US GDP per capita, not the effects of unusually high death rates from accident of injury. For information, the most recent data (which were used to make these calculations) on average standardised death rates per 100000 population from accident or injury over 1980-1999 for land transport, suicides, homicides, and falls, respectively are 17.4, 11.4, 9.2, and 4.6 for the United States and 15.5, 13.3, 3.0, and 10.4 for the OECD average (OECD Health Data, 2008). Life expectancy at birth on average over 1980-1999 was 75.3 years for both the United States and the OECD average (29 countries) (OECD Health Data, 2008).

2. These causes of death, referred to below as external, include: land transport accidents; intentional self-harm; accidental falls; and assaults.

3. This study used factor analysis to construct a deprivation index consisting of 11 education, occupation, wealth, income distribution, unemployment, poverty, and housing quality indicators.

4. These results are broadly corroborated in a study by Meara, Richards and Cutler (2008), which finds that all of the increase in US life expectancy at age 25 since the 1980s occurred in the better-educated population (defined as persons with 13 years or more of education, which corresponds to any college-level education). Life expectancy did not rise significantly for the lesser-educated population. 
5. Specifically, the infant mortality rate reflects the effects of economic and social conditions on the health of mothers and newborns as well as the effectiveness of health systems (OECD, 2007).

6. ICD-10 refers to the International Statistical Classification of Diseases and Related Health Problems (10 ${ }^{\text {th }}$ Revision).

7. The share of public expenditure in the United States is, however, understated compared with some countries (including Australia and Germany) where tax expenditures to encourage the purchase of private health insurance are included in the public share. Such expenditures are high in the United States $(2 \%$ of GDP) by international comparison.

8. Anderson et al., (2003) reached the same conclusion when they conducted a similar exercise a few years ago.

9. Medicare Part D provides cover for outpatient prescription drugs. Persons eligible for Medicare may enrol for Part D cover.

10. According to Agrisano et al. (2007), $\$ 84$ billion of the $\$ 98$ billion in excess spending on administration can be traced to private stakeholders. These authors estimate that in the US private sector, some $64 \%$ of the administrative costs incurred by private payers are due to underwriting health risks, sales and marketing costs that do not arise in the public systems of most OECD countries. Agrisano et al. (2007) report further that in the public sector, administrative expenses account for 3\% of the Medicare budget and 3-5\% of the Medicaid system, compared with 2\% spent in Britain's National Health Service.

11. These conditions are: heart disease; high blood pressure; high cholesterol; stroke/cardiovascular disease; asthma; arthritis; osteoporosis; and cancer.

12. Estimates of overweight and obesity rates in Australia, the Czech Republic, Luxembourg, New Zealand, the United Kingdom, and the United States are derived from health examinations in which actual measures of people's height and weight are taken. Data collection in other OECD countries is by self-reporting. Based on experience with both methodologies in the United States, self reporting tends to result in underestimates of overweight and obesity incidence in the population (OECD, 2007).

13. Angrisano et al. (2007) find that the prevalence of 130 diseases, including the most common disease groups, is not much greater in the United States than in peer countries (Japan, Germany, France, Italy, Spain, and the United Kingdom). The slightly higher prevalence of these diseases in the United States than in the other countries only adds $\$ 25$ billion to treatment costs in the United States. This compares with the authors' estimate of the excess of expenditure in the United States compared with these countries after adjusting for GDP per capita of $\$ 477$ billion in 2005 (out of total expenditure of $\$ 1.9$ trillion), as noted above.

14. Professional malpractice insurance premiums amounted to approximately $7 \%$ of total physicians' expenses in 2000, which is similar to their share in expenses in 1970 (Rodwin, Chang, and Clausen, 2006).

15. The number of uninsured persons actually declined in 2007 , to 45.7 million, from 47.0 million the year before. This decline reflected an expansion in the number of people covered by government health insurance programmes. It should also be noted that around 5 million of the uninsured are uninsured for less than one year. A further $3 \frac{1}{2} 2$ million are illegal immigrants.

16. SCHIP is an expansion to the public Medicaid programme for lower-income families. It started in 1997. States have expanded eligibility at varying rates since its inception, resulting in a steady number of uninsured children after 2000. There is currently a great deal of uncertainty about the future of SCHIP; there was bipartisan agreement for re-authorisation of the programme in 2007 but the Bill was vetoed by the President a number of times without enough support among Congress to override the veto. 
17. While almost all large firms offer health insurance benefits, only about $59 \%$ of employers at small firms (3-199 workers) do so. This percentage has been falling since 1999, mainly on account of rising costs (The Kaiser Family Foundation and Health Research and Education Trust, 2007). New small firms (less than 5 years of existence) are much less likely to offer employer-sponsored health insurance than are older smaller firms (Jacobs and Claxton, 2008).

18. In addition to individuals working in firms that do not offer health insurance to any employees, about $20 \%$ of workers in firms with insurance plans are not eligible (mostly part-time workers).

19. Estimates of premiums came from those available to firms with fewer than ten workers using the 2004 Medical Expenditure Panel Survey Insurance Component.

20. Loading is the proportion of the insurance premium not going to pay medical claims.

21 An emergency medical condition is defined in The Emergency Medical Treatment Act (EMTALA, which was passed as part of the Consolidated Omnibus Budget Reconciliation Act of 1986) as:

"A medical condition manifesting itself by acute symptoms of sufficient severity (including severe pain) such that absence of immediate medical attention could reasonably be expected to result in:

- placing the health of the individual (or, with respect to a pregnant woman, the health of the woman or her unborn child) in serious jeopardy,

○ serious impairment to bodily functions, or

○ serious dysfunction of any bodily organ or part, or

- with respect to a pregnant woman who is having contractions - that there is inadequate time to effect a safe transfer to another hospital before delivery, or that the transfer may pose a threat to the health or safety of the woman or her unborn child."

22. Uncompensated care is care provided to uninsured persons for which payment is due but cannot be collected.

23. A survey of individuals in a Los Angeles emergency room showed that $38 \%$ of respondents would trade their current emergency room visit for a visit to a doctor's office within three days (Grumbach et al., 1993).

24. Treatment of the uninsured in emergency rooms is not, however, the main reason that they are overcrowded in the United States. Rather, the main group contributing to such overcrowding is individuals with Medicaid. They often seek care in emergency departments because they are unable to find a primary care physician willing to treat them for Medicaid fee rates, which are set by the government.

25. They define the underinsured as insured persons with at least one of the following three indicators of financial exposure relative to income: out-of-pocket medical expenses for care amounted to $10 \%$ of income or more; among low-income adults (below $200 \%$ of the federal poverty line), medical expenses amounted to at least $5 \%$ of income; or deductibles equalled or exceeded $5 \%$ of income.

26. The underinsured in the 19-64-age group correspond to approximately 9\% of the total population in 2007 .

27. A deductible is the amount of healthcare costs that the individual must pay per year before receiving any reimbursements from the health insurance company. A copayment is the fixed amount the individual pays each time they purchase an insured medical good or service. Coinsurance means that the patient pays a percentage of each medical bill. 
28. Moral hazard, of course, is also a concern in social insurance schemes.

29 The other factors that account for this difference in loading charges are: that fixed costs of administering a plan can be spread over more beneficiaries in a large-group plan; and that such plans can negotiate lower premiums with insurers, lowering their profit margins.

30. The typical worker is assumed to be in the $15 \%$ federal income tax bracket and to face a $5 \%$ state tax rate and a $15.3 \%$ combined payroll tax rate.

31. Out-of-pocket expenses include both cost sharing and payments for healthcare services that are not covered by insurance. The latter payments can be thought of as an extreme form of cost sharing, in which the patient cost share is $100 \%$.

32. Gruber and Lettau (2004) find an elasticity of firms offering health insurance to their employees with respect to the after-tax price of health insurance of -0.3 , with this response being concentrated in small firms. Assuming that the tax exemption reduces the after-tax price of health insurance by $35 \%$, removing it would increase this price by $50 \%$, leading to a $15 \%$ decline in firms offering health insurance. There is also empirical evidence (Gruber and Washington, 2005) that changes in the after-tax price of employer-sponsored health insurance do not affect the odds of employees taking it up. Together, these pieces of evidence do not support the view that removal of the tax exclusion would lead to the collapse of individual employer-sponsored schemes.

33. Gruber (2008) assumes that tax credits of $\$ 380$ per individual and $\$ 950$ per family are given to those with incomes between $300 \%$ and $400 \%$ of the poverty line, falling to $\$ 120$ per individual and $\$ 340$ per family for those earning between $400 \%$ and $500 \%$ of the poverty line.

34. Employers are required to establish a section 125 "cafeteria plan", but not to fund it. Participation in the fund by the employee, however, qualifies him or her for the federal tax exclusion.

35. In the Republican Presidential candidate's programme, termination of the tax exclusion would be accompanied by tax credits for persons purchasing health insurance.

36. Gruber (2008) considers the effects of extending Medicaid to all individuals under $100 \%$ and $185 \%$ of the poverty line, respectively as a stand-alone reform. The more restrictive expansion would reduce the number of uninsured persons by 5 million. The deadweight costs of crowding out private insurance would be modest in this case - the crowd-out rate (1- change in uninsured/change in publicly insured) is only $17 \%$. Such an expansion in Medicaid would cost approximately $\$ 26$ billion per year. The larger expansion would reduce the number of uninsured persons by 10 million but would have a much higher crowd-out rate (25\%). This policy would cost $\$ 47$ billion.

37. This would occur if the increase in health expenditure resulting from the measures to reduce the after-tax price of health insurance outweighted the reduction caused by the abolition of the tax exclusion, which has been estimated to be $4 \frac{1}{2}$ per cent t0 141/2 per cent of total health expenditure (Feldman and Dowd, 1991).

38. The CBO (2007a) estimates labour-supply elasticities by earnings groups, to be the following: lowest decile, 0.168; second decile, 0.126; third and fourth deciles, 0.084; fifth and sixth deciles, 0.063; and top four deciles, 0.028 .

39. Medicare Parts A, B, and C pre-date Part D. Generally speaking, Medicare Part A is free to eligible recipients and helps pay for in-hospital care. Part B is optional and helps pay for regular medical care (e.g., doctor's bills, X-rays, laboratory tests). Individuals who choose to enrol in Part B must pay a premium, a deductible and co-payments. Medicare Part C (originally called Medicare + Choice, renamed Medicare Advantage in 2003 when certain rules were changed under the MMA to give enrolees better benefits and lower costs) became available in 1997 to persons eligible for Part A and enrolled in Part B. Under Part C, private health insurance companies can contract with the federal government to offer 
Medicare benefits through their own policies. Until recently, insurance companies that did so could offer Medicare beneficiaries health coverage not only through private fee-for-service (PFFS) plans, but also through managed care plans (such as HMOs) and Preferred Provider Organisations (PPOs). Following recent legislation, Medicare Advantage PFFS plans must be converted into PPOs. For more information, see http://www.medicare.org/index.php?option=com_frontpage\&Itemid=1

40. The CBO (2007a) estimates that ageing accounts for $27 \%$ of the total projected increase in spending on Medicare, Medicaid, and Social Security as a share of GDP through 2050 and 20\% through 2082, assuming that ageing is the only factor driving growth in spending for these entitlement programmes (i.e., assuming that healthcare costs per capita rise at the same rate as GDP per capita). Alternatively, if the ageing factor were removed from the projections, spending on these entitlement programs as a share of GDP would be $39 \%$ lower through 2050 than if ageing were a factor in the calculations and 38\% lower through 2082. The ageing effect in the second set of calculations is larger because it is amplified by faster growth in healthcare costs per individual than in GDP per capita. 


\section{Bibliography}

American Medical Associations (AMA) (2008), "Member Connect Survey: Physicians' reactions to the Medicare Physician Payment Cuts", American Medical Association Division of Market Research and Analysis.

Anderson, G., U. Reinhardt, P. Hussey, and V. Petrosyan, (2003), "It's The Prices, Stupid: Why The United States Is So Different From Other Countries," Health Affairs 22.3: 89-105.

Angrisano, C., D. Farrell, B. Kocher, M. Laboissiere, S. Parker (2007), "Accounting for the Cost of Health Care in the United States," McKinsey Global Institute, January.

Bernanke, B., (2008), "Challenges for Health-Care Reform", Speech at the Senate Finance Committee Health Reform Summit, Washington D.C., Board of Governors of the Federal Reserve System.

Blumberg, L.J. (2001), "Potential for expanding coverage”, Tax Policy Center.

Bundorf, M.K., and M.V. Pauly (2006), "Is health insurance affordable for the uninsured?," Journal of Health Economics 25, 650-673.

Card, D., C. Dobkin and N. Maestas, (2007), “Does Medicare Save Lives?', NBER Working Paper No. 13668, November.

Chandra A., J. Gruber and R. McKnight, (2007), "Patient Cost-Sharing, Hospitalization Offsets, and the Design of Optimal Health Insurance for the Elderly", NBER Working Paper No. 12972.

Chernew, M., D. Cutler, and P. Keenan, (2005), "Increasing Health Insurance Costs and the Decline in Insurance Coverage," Health Services Research 40.4: 1021-1039.

Clemans-Cope, L., and B. Garrett, (2007), "Changes in Employer-Sponsored Health Insurance Sponsorship, Eligibility, and Participation: 2001 to 2005," Kaiser Commission on Medicaid and the Uninsured, Publication No. 7599.

Cogan, J.F., R.G. Hubbard, and D.P. Kessler, (2005), Healthy, Wealthy, and Wise: Five Steps to a Better Health Care System. Washington, DC: AEI Press.

Congressional Budget Office, (2007a), "the Effect of Tax Changes on Labour Supply in CBO's Microsimulation Tax Model”, Background paper, April.

Congressional Budget Office (CBO) (2007b), The Long-Term Outlook for Health Care Spending, Washington DC.

Congressional Budget Office (CBO) (2007c), CBO’s Health Insurance Simulation Model: A Technical Description. Washington, DC. 


\section{ECO/WKP(2009)6}

Congressional Budget Office (CBO) (2008), "Opportunities to increase efficiency in health care", Statement of Peter R. Orszag at the Health Reform Summit of the Committee on Finance, U.S. Senate.

Congressional Research Service (CRS) (2008), "Health Insurance Reform and the $110^{\text {th }}$ Congress", June.

Cutler, D., (2007), “The Lifetime Costs and Benefits of Medical Technology," Journal of Health Economics 26.6: 1081-1100.

Cutler, D. and M. McLellan, (2001), "Is Technological Change in Health Care Worth It?," Health Affairs, 20 No. 5, pp 11-29.

Danzon, P., and M. Furakawa, (2008), "International Prices and Availability of Pharmaceuticals In 2005," Health Affairs 27.1: 221-233.

Doyle, J. (2005), "Health Insurance, Treatment and Outcomes: Using Auto Accidents as Health Shocks", NBER Working Paper 11099, February.

Dubay L, Holahan J and Cook A., (2006), "The Uninsured and the Affordability of Health Insurance Coverage", Health Affairs (Web Exclusive), November.

Feldman R, and B.E. Dowd, (1991), "A New Estimate of the Welfare Loss of Excess Health Insurance", American Economic Review, Vol. 81, No. 1, March 1991, pp. 297-301.

Fogel, R. (2004), The Escape from Hunger and Premature Death, 1700-2100, Cambridge University Press.

Frank, R. G. and J. P. Newhouse, (2007), "Mending the Medicare Prescription Drug Benefit: Improving Consumer Choices and Restructuring Purchasing", Hamilton Project Discussion Paper 2007-03, April, The Brookings Institution.

Frank, R. G. and J. P. Newhouse, (2008), "Should drug prices be negotiated under Part D of Medicare? And if so, how?", Health Affairs, Vol. 27, No. 1.

GAO, (2008), Competitive bidding for medical equipment and supplies could reduce program payments, but adequate oversight is critical, 6 May.

Glied, S. and B. Mahato (2008), "The Widening Health Care Gap between High-and-Low-Wage Workers", Commonwealth Fund Publication No. 1129, www.commonwealthfund.org.

Gruber, J. (2008), “Covering the uninsured in the U.S.”, NBER Working Paper No. 13758, January.

Gruber, J. and M. Lettau (2004), "How Elastic is the Firm's Demand for Health Insurance?", Journal of Public Economics, No. 88, pp. 1273-1294.

Gruber, J., and B. Madrian (1996), "Health Insurance and Early Retirement: Evidence from the Availability of Continuation Coverage", in Advances in the Economics of Ageing, David Wise, ed.; pp. 115-143.

Gruber, J., and E. Washington (2005), "Subsidies to Health Insurance Premiums and the Health Insurance Market", Journal of Health Economics, No. 24, pp. 253-276. 
Grumbach, K., D. Keene and A. Bindman (1993), "Primary Care and Public Emerging Department Overcrowding", American Journal of Public Health, Vol. 83, Issue 3, pp. 372-378.

Hadley, J. and J. Holahan, (2004), "The Cost of Care for the Uninsured: What Do We Spend, Who Pays and What Would Full Coverage Add to Medical Spending?", Issue Update No. 7804, Washington: Kaiser Commission on Medicaid and the Uninsured, May 10.

Hattersly, Lin (1999), “Trends in Life Expectancy by Social Class - An Update," Health Statistics Quarterly, Vol. 2 (Summer 1999), pp 16-24, Office for National Statistics.

Herring, B., (2005), "The Effect of the Availability of Charity Care to the Uninsured on the Demand for Private Health Insurance," Journal of Health Economics 24.2: 225-252.

Institute of Medicine (2002), Care without Coverage: Too Little, Too Late, Washington; National Academy Press.

Jacobs, P., and G. Claxton, (2008), "Offer Rates for Smaller Establishments by Business Age," Kaiser Family Foundation, May 2008.

Joumard, I., C. André, C. Nicq, and O. Chatal (2008), "Health Status Determinants: Lifestyle, Environment, Health Care Resources and Efficiency, Economics Department Working Papers No. 627, OECD, Paris.

Keehan, S., A. Sisko, C. Truffer, S. Smith, C. Cowan, J. Bisal, M. Clemens, and the National Health Expenditure Accounts Projections Team (2008), "Health Spending Projections Through 2017: The Baby-Boom Generation Is Coming to Medicare," Health Affairs 27.2: w145-w155.

Kessler, D. and M. McClellan, (1996), “Do Doctors Practice Defensive Medicine?", The Quarterly Journal of Economics, Vol. 2, May, pp. 353-390.

Kitagawa, E. M. and P. M. Hauser (1973), Differential Mortality in the United States: A Study in Socioeconomic Epidemiology, Cambridge, Massachusetts, Harvard University Press.

Kronick, R., and T. Gilmer, (1999), "Explaining the decline in health insurance coverage, 1979-1995," Health Affairs 18.2: 30-47.

Kunst, A. E., V. Bos, O. Andersen, et al. (2004), "Monitoring of trends in socioeconomic inequalities in mortality: experiences from a European project", Demographic Research, Special Collection 2, Article 9, 229-254.

Lemieux, J., T. Chovan and K. Heath, (2008), "Medigap Coverage and Medicare Spending: A Second Look", Health Affairs, Vol. 27, No. 2.

Leonhardt, D. (2008), "High Medicare costs, courtesy of Congress", New York Times, 25 June.

Manning, W., et al., (1987), "Health Insurance and the Demand for Medical Care," American Economic Review 77.3, 251-277.

Medicare Payment Advisory Committee (MedPAC), (2008), March 2008 Report to the Congress.

Meara, E., S. Richards, and D. Cutler, (2008), "The Gap Gets Bigger: Changes in Mortality and Life Expectancy by Education, 1981-2000”, Health Affairs 27, No. 2, pp. 350-360. 
Meara, E., M. Rosenthal, A. Sinaiko and K. Baicker, (2008), "State and Federal approaches to health reform: what works for the working poor?", NBER Working Paper No. 14125.

Murphy, K., and R. Topel, (2006), "The Value of Health and Longevity," Journal of Political Economy 114.4: 871-904.

New Zealand Department of Health (2007), Social Report.

Nolte, E., and C.M. McKee, (2008), "Measuring the Health of Nations: Updating an Earlier Analysis," Health Affairs 27.1: 58-71.

Ohsfeldt, R.L., and J.E. Schneider (2006), The Business of Health: the Role of Competition, Markets, and Regulation, Washington, AEI Press.

OECD (2007), Health at a Glance, OECD Indicators, Paris.

OECD (2008), Pharmaceutical Pricing Policy in a Global Market, Paris.

Phelps, C. E (2002), Health Economics, 3d ed. (Boston: Addison-Wesley, 2002), 343.

Rodwin, M., H. Chang, and J. Clausen (2006), "Malpractice Premiums and Physicians' Income: Perceptions of a Crisis Conflict with Empirical Evidence", Health Affairs 25, No. 3, pp. 750-758.

Schoen, C., S. Collins, J. Kriss and M. Doty, (2008), "How Many are Underinsured? Trends Among U.S. Adults, 2003 and 2007”, Health Affairs 27, No. 4, W298-W309.

Singh, G. K., and M. Siahpush, (2006), "Widening Socioeconomic Inequalities in U.S. Life Expectancy, 1980-2000”, International Journal of Epidemiology 2006; 35: pp. 969-979, Oxford University Press.

Skinner, J.S., D.O. Staiger, and E.S. Fisher, (2006), Is Technological Change In Medicine Always Worth It? The Case Of Acute Myocardial Infarction," Health Affairs 25.2: w34-w47.

Sturm, R. (2002), "The Effects of Obesity, Smoking and Drinking on Medical Problems and Costs", Health Affairs, Vol. 21, No. 2, pp. 245-253, March/April.

The Kaiser Family Foundation and Health Research and Education Trust (2007), "Employer Health Benefits, 2007 Summary of Findings".

Thompson, D. and A. Wolfe, (2001), "The Medical-Care Burden of Obesity', Obesity Reviews, No. 2, International Association for the Study of Obesity, pp. 189-197.

Thorpe, K., D. Howard, and K. Galactionova, (2007), "Differences In Disease Prevalence As A Source of the U.S.-European Health Care Spending Gap," Health Affairs 26.6: w678-w686.

Wilkins, R., J. Bathelot and E. Ng, (2002), "Trends in mortality by Neighborhood Income in Urban Canada from 1971 to 1996", Statistics Canada, Supplement to Health Reports, Vol. 13, Catalogue 82-003. 


\section{WORKING PAPERS}

The full series of Economics Department Working Papers can be consulted at www.oecd.org/eco/Working_Papers/

664 The role of $R \& D$ and technology diffusion in climate change mitigation: New perspectives using the WITCH model

(February 2009) Valentina Bosetti, Carlo Carraro, Romain Duval, Alessandra Sgobbi and Massimo Tavoni

663. Long-run GDP growth framework and scenarios for the world economy

(January 2009) Romain Duval and Christine de la Maisonneuve

662. Realising South Africa's employment potential

(January 2009) Geoff Barnard

661. Making the most of Norwegian schools

(January 2009) Romina Boarini

660 Can the financial sector continue to be the main growth engine in Luxembourg?

(January 2009) Arnaud Bourgain, Patrice Pieretti and Jens Høj

659. Fiscal policy responsiveness, persistence, and discretion

(December 2008) António Afonso, Luca Agnello, Davide Furceri

658. The economics of climate change mitigation: policies and options for the future

(December 2008) Jean-Marc Burniaux, Jean Chateau, Romain Duval and Stéphanie Jamet

657. Maximising Mexico's gains from integration in the world economy

(December 2008) David Haugh, Roselyne Jamin and Bruno Rocha

656. How do taxes affect investment and productivity? An industry-level analysis of OECD countries (December 2008) Laura Vartia

655. Strategies for countries with favourable fiscal positions

(November 2008) Robert Price, Isabelle Joumard, Christophe André and Makoto Minegishi

654. Monetary transmission mechanism in Central and Eastern Europe: Surveying the Surveable (November 2008) Balázs Égert and Ronald MacDonald

653. An Overview of the OECD ENV-Linkages Mode1

Jean-Marc Burniaux and Jean Château

652. Reforming the labour market in Japan to cope with increasing dualism and population ageing (November 2008) Randall S. Jones

651. Enhancing the productivity of the service sector in Japan

(November 2008) Randall S. Jones and Taesik Yoon

650. Reforming the tax system in Japan to promote fiscal sustainability and economic growth

(November 2008) Randall S. Jones and Masahiko Tsutsumi 
ECO/WKP(2009)6

649. What Drives the NAIRU? Evidence from a Panel of OECD Countries

(November 2008) Christian Gianella, Isabell Koske, Elena Rusticelli and Olivier Chatal

648. Short-term distributional effects of structural reforms: selected simulations in a DGSE framework (October 2008) Annabelle Mourougane and Lukas Vogel

647. Speed of adjustment to selected labour market and tax reforms

(October 2008) Annabelle Mourougane, Lukas Vogel

646. The challenge of monetary policy in Turkey

(October 2008) Olcay Çulha, Ali Çulha and Rauf Gönenç

645. Improving cost-effectiveness in the health-care sector in Iceland

(October 2008) Hannes Suppanz

644. Understanding Russian regions' economic performance during periods of decline and growth - an Extreme Bound Analysis approach

(October 2008) Rüdiger Ahrend

643. Do tax structures affect aggregate economic growth? Empirical evidence from a panel of OECD countries

(October 2008) Jens Arnold

642. Accounting for one-off operations when assessing underlying fiscal positions

(October 2008) Isabelle Joumard, Makoto Minegishi, Christophe André, Chantal Nicq and Robert Price

641. Do corporate taxes reduce productivity and investment at the firm level? Cross-country evidence from the Amadeus dataset

(October 2008) Cyrille Schwellnus and Jens Arnold

640. The challenge of rapidly improving transport infrastructure in Poland

(September 2008) Rafal Kierzenkowski

639. Bridging the housing gap in Poland

(September 2008), Rafal Kierzenkowski

638. Improving the business and investment climate in Indonesia

(September 2008), Diego Moccero

637. Growth performance and policy challenges

(September 2008), Luiz de Mello

636. A taxonomy of instruments to reduce greenhouse gas emissions and their interactions (September 2008), Romain Duval

635. Quantifying the effect of financial conditions on US activity

(September 2008) Stéphanie Guichard and David Turner 